\title{
From egg production to recruits: connectivity and inter- annual variability in the recruitment patterns of European anchovy in the northwestern Mediterranean
}

\author{
Ospina-Alvarez Andres ${ }^{1,2, *}$, Catalan Ignacio A. ${ }^{3}$, Bernal Miguel $^{4}$, Roos David ${ }^{5}$, Palomera Isabel ${ }^{2}$
}

${ }^{1}$ Center for Marine Conservation \& Department of Ecology, Biological sciences Faculty, Pontificia Universidad Católica de Chile, Alameda 340, C.P. 6513677, Casilla 193, Correo 22, Santiago, Chile

${ }^{2}$ Department of Renewable Marine Resources, Institute of Marine Sciences (ICM, CSIC). Passeig Maritim de la Barceloneta 37-49, 08003 Barcelona, Spain

${ }^{3}$ Department of Ecology and Marine Resources, Mediterranean Institute for Advanced Studies (IMEDEA-CSIC/UIB). C/ Miquel Marques 21, 07190, Esporles, Balearic Islands, Spain

${ }^{4}$ Centro Oceanográfico de Cádiz, Instituto Español de Oceanografía. Puerto Pesquero, Muelle de Levante s/n, 11006, Cádiz, Spain

${ }^{5}$ IFREMER, UMR 212 EME, Boulevard Jean Monnet, BP 171, Sète Cedex 34203, France

* Corresponding author : Andres Ospina-Alvarez, email address : aospina.co@me.com

\begin{abstract}
:
We show the application of a Spatially-Explicit Individual-Based Model (SEIBM) to understand the recruitment process of European anchovy. The SEIBM is applied to simulate the effects of inter-annual variability in parental population spawning behavior and intensity, and ocean dynamics, on the dispersal of eggs and larvae from the spawning area in the Gulf of Lions (GoL) towards the coastal nursery areas in the GoL and Catalan Sea (northwestern Mediterranean Sea). For each of seven years (2003-2009), we initialize the SEIBM with the real positions of anchovy eggs during the spawning peak, from an acoustics-derived eggs production model. We analyze the effect of spawners' distribution, timing of spawning, and oceanographic conditions on the connectivity patterns, growth, dispersal distance and late-larval recruitment (14 mm larva recruits, R14) patterns. The area of influence of the Rhône plume was identified as having a high probability of larval recruitment success (64\%), but up to $36 \%$ of R14 larvae end up in the Catalan Coast. We demonstrate that the spatial paths of larvae differ dramatically from year to year, and suggest potential offshore nursery grounds. We showed that our simulations are coherent with existing recruitment proxies and therefore open new possibilities for fisheries management.
\end{abstract}




\section{Highlights}

- Biological and ecological processes of European anchovy relevant to recruitment and connectivity are reviewed. An egg and larval dispersal model was used to explore European anchovy connectivity in NW Mediterranean. Rhône River plume plays an important role in the modulation of the spawning areas and late larval recruitment. Potential offshore nursery grounds for European anchovy are suggested. Indices from a dispersal model are coherent with existing recruitment proxies for European anchovy. The use of recruitment indices from dispersal models open new possibilities for fisheries management.

Keywords : Anchovy, Connectivity, Mediterranean, Recruitment, Larval, Eggs, Nursery, Transport, Dispersion, Ichthyoplankton, Acoustics 


\section{Introduction}

\subsection{Background}

With advances in mathematical and computational approaches, many threedimensional hydrodynamic models have been developed to reproduce the dynamical characteristics of the ocean and study processes such as sediment transport, geochemical cycles, movement of pollutants, thermal structure, wave propagation, etc. (Chassignet et al., 2006). Similarly, under the assumption that packets of larvae can be modeled in the same way as water parcels, these high resolution hydrodynamic models provide opportunities for resolving more realistic larval transport pathways (Hermann et al., 2001), which are almost impossible to track directly (Cowen et al., 2007; Thorrold et al., 2007; Werner et al., 2007). Spatially explicit individual-based models (SEIBMs) have been applied extensively worldwide and have been increasingly used both as descriptive tools of larval dispersal for a particular marine system and for general evaluation of the role of different biological and environmental factors on dispersal, connectivity and population dynamics (Bartsch et al., 2004; Huggett et al., 2003; Metaxas and Saunders, 2009; Mullon et al., 2002; Ospina-Alvarez et al., 2013; Parada, 2003; Pineda et al., 2007; Werner et al., 2001).

The recruitment of small pelagic fish is not deterministic; its variability and the causes thereof, rather than precise predictions of the year-class size arising from a given stock in a given year, need to be understood and quantified (Needle, 2002). In this context, SEIBMs are important because, by incorporating realistic descriptions of habitat, hydrodynamics, larval transport pathways and adult growth and survival, they can provide a mechanistic understanding of how recruitment variability arises from various modeled forces and how local populations may be interconnected (Kendall et 
al., 1984; Werner et al., 2001). Additionally, SEIBM's have been used to understand how potential connectivity is highly variable in time and space, as a function of different biological and physical processes, affecting the metapopulations growth rates and equilibrium abundances (Watson et al., $2011 ; 2012)$. This variability creates uncertainty in the assessment of fish recruitment and the resulting forecasts of sustainable yields (Siegel et al., 2008). Spatially explicit IBMs allow the investigation of the role of emerging properties in recruitment given the mechanistic assumptions used (Chassignet et al., 2006; Lomnicki, 1992), and its results have also proven to be capable of improving fisheries management frameworks and the development of viable stock recovery plans and management strategies (Hermann et al., 2001; Hinrichsen et al., 2011; Treml et al., 2012; Werner et al., 2001).

Fisheries stock recruitment models have generally ignored connectivity among populations, and local density-dependent factors have been considered the most important parameter for the regulation of populations (Cowen et al., 2007; Hilborn, 2003; Thorrold et al., 2007; Werner et al., 2007). Existing tools for management strategy evaluation, such as acoustic surveys or the Daily Egg Production Method (DEPM), can already incorporate spatially explicit estimates of the distributions of early life stages as well as information on reproductive biology and environmental and ecological information about spawning habitats but do so in a static way. SEIBMs capture important aspects of population dynamics, including drift and transport processes, to quantify the level of connectivity and exchange between spawning and nursery areas in a real context (Ayata et al., 2010; Bartsch et al., 2004; Huggett et al., 2003; Metaxas and Saunders, 2009; Mullon et al., 2002; Ospina-Alvarez et al., 2013; Parada, 2003; Pineda et al., 2007; Werner et al., $2007 ; 2001)$, and are the natural tools to incorporate realistic information on spawners' behavior. 
Small pelagic fish are an important and abundant constituent of many marine ecosystems, playing a dominant role in food webs (Needle, 2002; Pikitch et al., 2012). Fisheries for small pelagic fish are among the largest in the world, and global demand for small fish and derived (i.e., processed) products is increasing (Garcia and Rosenberg, 2010; Kendall et al., 1984; Werner et al., 2001). The commercial exploitation of small pelagic fish in the northwestern Mediterranean has been significant since the early 1940s. Due to improvement in fishing technology in the 1960s the exploitation of European anchovy substantially increased (Palomera et al., 2007). Anchovies, and other small pelagic fish, are identified as an important bottom-up flow control group (Bakun, 1996; Cury et al., 2000; Dunne et al., 2004; Freón et al., 2005; Libralato et al., 2006; Pauly and Christensen, 1995; Quentin Grafton et al., 2010; Sibert et al., 2006; A. D. M. Smith et al., 2011). Therefore, fluctuations in their populations due to fishing and/or natural factors may have a major impact on the whole ecosystem (Bombace, 2001; Katara et al., 2011; Koutsikopoulos and Le Can, 1996; Lejeusne et al., 2010; Massé, 1996). The European anchovy Engraulis encrasicolus is a highly valued fishery resource in the western Mediterranean Sea. Several studies have been conducted regarding diverse aspects of the biology and ecology of the species in this area to improve the tools available for fishery management (Palomera et al., 2007).

Recently, individual-based models for anchovies in the Mediterranean have focused on developing adequate biological algorithms to simulate realistic spatial variations in eggs and larvae (Ospina-Alvarez et al., 2012a; 2012b). Data on the anchovy nursery grounds in the NW Mediterranean are sparse; García and Palomera (1996) showed that the main concentration of larvae was from 10 to 50 miles offshore in the NW Mediterranean; Ospina-Alvarez et al. (2012a) found, in a SEIBM experiment where virtual eggs were 
released over the northwestern Mediterranean, that larvae from the Gulf of Lions (east and west), Ebro Delta and Gulf of Valencia spawning areas had a higher probability of reaching nursery areas compared with larvae from the Palamós and Barcelona areas. Nevertheless, from a spatial and temporal perspective, data on the abundance and locations of larval retention at hatching time are still relatively scarce and patchy in comparison with data on egg distribution or preferred areas for juveniles and adults (Peck et al., 2013). The ecological and economic importance of small pelagic fish demands the adoption of ecosystem-based management. This implies management of renewable resources that integrates knowledge of the structure and dynamics of the ecosystems, including humans, linked to the target species (FAO Fisheries Department, 2003). The most common management measure used in small pelagic fisheries is limiting the catch by setting an annual total allowable catch (TAC) (Barange et al., 2009). However, the TAC approach was not designed to take into account the life history of a species, the variability in its stocks, or its ecosystem functions and services (Arkema et al., 2012; Pauly et al., 2002; Pikitch et al., 2012). Moreover, the management of small pelagic fish should allow for the maintenance of genetic variation to ensure population sustainability and establish management models that allow the incorporation and estimation of the uncertainty of biotic and abiotic factors. In conclusion, the choice of management tools to achieve ecosystembased management in a given situation will depend on data availability and the associated level of uncertainty (Pikitch et al., 2012).

\subsection{Aims}

Several questions were addressed in this study to deepen our understanding of European anchovy recruitment dynamics: Where are the most likely nursery areas for the different model conditions? Which spawning areas are the most suitable (i.e., will produce higher late larval recruitment)? How does 
spawners' distribution shape the larval distribution? What is the level of connectivity between different areas in the NW Mediterranean (e.g., Gulf of Lions and Balearic Sea)? Finally, what are the respective roles of hydrodynamic processes and larval mortality in larval dispersal and recruitment?

To address these questions, we analyzed simulated patterns of larval distribution and paths using a methodological approach that combines numerical and statistical modeling. These analyses aimed to make robust inferences about the main factors affecting late larval recruitment success and its relationship to the inter-annual variation in the distribution of spawners.

\section{Methods}

\subsection{Acoustic data collection}

This study was performed in the NW Mediterranean (Fig. 1) using information extracted from eight cruises (PELMED 2003-2010), aboard the R/V l'Europe, conducted by IFREMER over the continental shelf of the Gulf of Lions (GoL). The aim of each cruise was to assess the stock of European anchovy (Engraulis encrasicolus) and Mediterranean sardine (Sardina pilchardus) populations using acoustic methods and continuous observations along regularly spaced (12 nautical miles) inshore-offshore transects (see Fig. 2 in Ospina-Alvarez et al., 2013). Acoustic sampling was performed with scientific split-beam echo sounders operating at $38 \mathrm{kHz}$ and calibrated following standard techniques (Foote et al. 1987). Data were recorded at a constant speed of 8 knots. The minimum sampling depth varied between 10 and $20 \mathrm{~m}$ depending on the area. The size of the Elementary Distance Sampling Unit (EDSU) was one nautical mile (nmi, $1.852 \mathrm{~km})$. Pelagic trawls were performed to identify target species. A complete description of the anchovy biomass estimation procedures based on PELagiques 
MEDiterranée (PELMED) acoustic surveys is available at IFREMER's institutional repository (Doray et al., 2010). The data from these surveys was transformed to initialize the SEIBM runs following the method developed by Ospina-Alvarez et al. (2013) (see section 2.2.3.1 for a detailed description).

\subsection{SEIBM description}

To assess the relative contributions of the inter-annual variation in spawners' distribution and hydrodynamic circulation to the dispersal of anchovy eggs and larvae, we applied a SEIBM consisting of an individual-based model of early life stages coupled with a 3D hydrodynamic model using a customized version of the open source modeling tool ICHTHYOP (Lett et al., 2008). In its biological module, our SEIBM included the following realistic behavior models: (1) egg buoyancy changing through development (Ospina-Alvarez et al., 2012a) and (2) a diel vertical migration (DVM) scheme structured by age and size (Ospina-Alvarez et al., 2012b). This choice was made to test the effect of the spawners' distribution under the most realistic conditions possible. Although the SEIBM is similar to the one presented by OspinaAlvarez et al. (2013), the experimental design in the present work is different. Ospina-Alvarez et al. (2013) used the SEIBM to prove that using the real distribution of eggs (based on egg distribution data from surveys for 2007 and 2008) produces results significantly different from those using random distributions. In the present paper, we used the model proposed by OspinaAlvarez et al. (2013) to initialize a series of 7 yearly simulations (2003-2010), which we use to analyze anchovy larval recruitment. The overall simulation is summarized in Fig. 2.

The description of the model follows the ODD protocol (Overview, Design concepts, Details) (Grimm et al., 2010) for describing IBMs. According to this scheme, an overview is first presented to explain the purpose of the 
model and its state variables, scales and process scheduling. However, as the main model has been already described in ODD terms (Lett et al., 2008), we will largely focus on the particularities of this version.

\subsubsection{SEIBM overview}

The model aims to explore how the spatiotemporal abundance and distribution of anchovy eggs interact with physical factors (e.g., ocean currents, temperature, salinity) to affect the dynamics of anchovy plank tonic stages. The model uses velocity, temperature and salinity fields obtained from the MARS-3D hydrodynamic model (see section 2.2.3.2). The SEIBM simulates the spatiotemporal dynamics of a small pelagic fish that spawns during the boreal summer, specifically June 10th and 20th and July 10th and 20th on seven consecutive years (2003-2009), and the advection of their early stages (i.e., eggs and larvae). These selected spawning dates fall within the peak of the anchovy-spawning period and are assumed to broadly depict the main summer circulation patterns for these two months in these years. This assumption is reasonable owing to the highly stable environment during summer in the NW Mediterranean (Basterretxea et al., 2012; Lazure and Dumas, 2008).

A point pattern of 10,000 virtual eggs for each year was determined using the spatial egg density from the model developed by Ospina-Alvarez et al. (2013) (Fig. 3). Essential assumptions of this approach are as follows: 1) the spatial location of the spawning fraction is given by the acoustics data; 2) this location does not change within the spawning season; 3) within-year growth does not affect the fecundity estimates; and 4) all individuals are mature at the time of the simulation. 
At the beginning of each time step, the environmental conditions (see section 2.2.3.2.) were used as inputs for the SEIBM using fields from the hydrodynamic model. Thereafter, information concerning the anchovy agents was updated, modifying the data on age, size, vertical position and the number of individuals using the mortality and 'out of the domain' procedures (see section 2.2.3.2.). Individuals (hereafter 'late larvae') were considered to be recruited to a particular area if they were larger than $14 \mathrm{~mm}$ in standard length (SL); this is the length at which they are considered to acquire a relatively fast swimming capacity (Somarakis and Nikolioudakis, 2010). This criterion defined "individual late larval recruitment success" (hereafter referred to as R14). In consequence, R14 is a binary response representing the 'success' or 'failure' of reaching a nursery area for each $14 \mathrm{~mm}$ larvae. Unless otherwise said (like 'larval recruitment' or 'late larval recruitment'), to avoid confusion, 'recruitment' in the text always refers to the individuals entering the fishery stock.

\subsubsection{Design concepts}

Basic principles: The new schemes used herein with respect to the description in Lett et al. (2008) include i) a reflective boundary condition at the coast, ii) a developmental time-dependent eggs buoyancy scheme that is based on a species-specific equation for the European anchovy (OspinaAlvarez et al., 2012a) (see section: 2.2.3.2. Egg development), iii) two-stage temperature-dependent developmental dynamics (see section: 2.2.3.2.) and iv) an age/stage-dependent vertical migration scheme (Ospina-Alvarez et al., 2012b) (see section: 2.2.3.2., Diel Vertical Migration).

Emergence: This study is based on a pattern-oriented modeling approach (Grimm and Railsback, 2005; Reuter et al., 2005) in which the model generates patterns that are not explicitly coded but that result instead from 
the collective interactions of the physical and biological elements comprising the model. We considered the spatial distribution of eggs, with spatial density gradients occurring as a result of the adult anchovy distribution. The simulated dispersion pattern results from the combination of the individual history of each particle and internal variables (e.g., growth), which depend on variations in the encountered external variables (e.g., temperature, currents). The number and state (e.g., size) of individuals reaching the nursery areas at the end of the simulation reflects all of the mechanisms and inputs of the model and thus permits unforeseen emergent patterns.

Adaptation: Note that although late larval recruitment success is a response of the model and represents the best estimate available, biological fitness (e.g., the ability to survive to reproductive age, succeed at finding a mate/mates and producing offspring) is not explicitly modeled. We have not included in this exercise the habitat quality, larval condition or parental effects. Furthermore, the ability of anchovy individuals to spawn in a given location to maximize the probability of the larvae ending up in a suitable nursery may be an adaptive trait serving to improve late larval recruitment, but this hypothesis still requires formal verification. In this work, and due to the lack of data, we will assume that any area in the NW Mediterranean with a depth of $<250 \mathrm{~m}$ will have a non-null potential as a late larval recruitment zone.

Stochasticity: To establish the appropriate number of particles in the transport experiments, we performed repeated trials in which we increased the number of particles at release $(1000,5000,10,000,15,000,20,000$ and $50,000)$, defined the ensemble average and standard deviation and determined the point at which these statistics stabilized (Brickman and P. C. Smith, 2002). We established that 10,000 particles represented the desired ensemble average. Thus, we assumed that no repetition of our runs was 
necessary and that only one simulation was necessary for each set of parameters and for each day.

Model outputs: The model output is primarily presented as charts of the distribution and abundance of larvae at a length of $14 \mathrm{~mm}$ and connectivity matrices. The number of late larval recruits in a particular geographical area is a function of the number of accumulated particles, which is summed for comparisons between areas.

\subsubsection{Details}

\subsubsection{Input data and initialization}

Two spawning zones and seven potential late larval recruitment (nursery) zones were established: Gulf of Lions (GoL) East and GoL West (spawning, potential auto-recruitment) and Palamós, Barcelona, Ebro Delta, Gulf of Valencia (GV) and the Balearic Islands (recruitment zones; see Fig. 4). These zones were chosen based on topography and the influence of different events associated with them: GoL East and Ebro Delta feature a wide shelf and influxes from large rivers; GoL West and GV also have a wide shelf; Palamós is an area with important submarine canyons that extend to the coast; Barcelona contains a narrow shelf; at the northern Balearic Islands there is potential retention derived from diversions of the Northern Current into the Balearic current (Fig. 1).

The daily egg production (number of stage-I eggs per square meter of sea surface) estimated from adult biomass was obtained by mean of acoustic surveys using the information collected during the PELMED surveys in June-July 2003-2010 and historical fecundity data. Briefly, this method uses data on sex ratios and applies them to the biomass and size structure estimated from the acoustic surveys. Additionally, a regression model 
between weight and batch fecundity is performed. The inter-annual egg production can be predicted by integrating the information about batch fecundity, mean weight, number of fish, sex ratio and mean spawning fraction. The initial fields for the spawning distributions were based on egg distribution data from the Generalized Additive Models (GAMs) constructed by Ospina-Alvarez et al. (2013). The spatial structure of the spawning distributions of anchovy allowed GAMs to be fitted that explained between $60 \%$ and $89 \%$ of the deviance in the survey station values for anchovy biomass and provided significant estimates of spatial and temporal trends for the data collected in eight acoustic surveys from 2003 to 2010. The resulting GAMs were used to provide 10,000 virtual eggs on given locations as input data for the SEIBMs for June 10th and 20th and July 10th and 20th from 2003 to 2009 (Fig. 3).

\subsubsection{SEIBM submodels}

Hydrodynamic model: MARS is a 3D primitive equation-free surface model applying the Boussinesq approximation and hydrostaticity; for a detailed description, see Lazure \& Dumas (2008). A description of the model configuration for the NW Mediterranean Sea is given by André et al. (2005). Spatial discretization is achieved using a staggered "C" grid (Arakawa and Lamb, 1977) and sigma vertical coordinates. The turbulent closure scheme used to compute the vertical turbulent diffusion coefficient is the Turbulent Kinetic Energy (TKE) model (Gaspar et al., 1990). To maintain horizontal mesoscale structures, horizontal viscosity is computed using a formulation proposed by Smagorinsky (1963) and dependent on local mesh dimensions and velocity gradients. For the coupling with the IBM, MARS-3D is used in its NW Mediterranean configuration (MENOR) with a horizontal resolution of $1.2 \mathrm{~km}$ and 30 sigma layers. The entire model domain covers the northern part of the Tyrrhenian Sea, the Ligurian Sea, the GoL and the Catalan Sea to 
the north of the Balearic Islands. Initial and boundary conditions were obtained from the Mediterranean Forecasting System (MFS) global model re-analysis, available since the year 2001 (Pinardi et al., 2003). MFS-model data on temperature, salinity, current and sea surface elevation, which are provided every $24 \mathrm{~h}$ with a $1 / 16^{\circ}(5-7 \mathrm{~km})$ resolution, were spatially and temporally interpolated into the MENOR grid. Atmospheric forcing was obtained every $3 \mathrm{~h}$ from a high-resolution $(3 \mathrm{~km})$ MM5 model embedded in the NCEP analysis for the years 2005, 2006 and 2007. Between 2001 and 2004, the results of the French Met-Office model ALADIN $(10 \mathrm{~km}$ resolution) were used as an alternative data source. MARS-3D for the NW Mediterranean has been run in an operational mode since the beginning of 2005, within the framework of the MOON project (http://www.moonoceanforecasting.eu), producing 3-hourly simulations.

The MARS fields were interpolated in time and space in the SEIBM to determine the values of the environmental state variables at any individual location. One time step represents 600 seconds, and the simulations were run for 30 days. The gridded time series output was saved every 160 minutes in a single netCDF file.

Egg development: Ten thousand particles (anchovy eggs) per run were distributed according to the section 2.2.3.1. The virtual eggs were released randomly in the first $15 \mathrm{~m}$ of the water column according to previous studies (Olivar et al., 2001; Palomera, 1991). During the incubation time, egg buoyancy has an influence on the horizontal and vertical trajectories of eggs, as well as their routes and hatching zones. A polynomial equation was fitted to estimate egg buoyancy considering the time from fertilization, the effect of sea water temperature and the sea water density at spawning following a previous study in the GoL (Ospina-Alvarez et al., 2012a). The total 
incubation time of anchovy eggs increases with decreasing temperature. Moreover, the duration of each egg stage is not constant; certain stages are longer than others (Bernal et al., 2012; 2011; Regner, 1996; 1985). Stagespecific egg development rates and total egg development times for Mediterranean anchovy were implemented in ICHTHYOP following the methods and estimates of Ospina-Alvarez et al. (2012a). As a consequence of egg buoyancy and hydrodynamics, each egg was located at a different depth at the time of hatching.

Larval growth: Larvae were forced to hatch at a fixed length of $2.79 \mathrm{~mm} \mathrm{SL}$, consistent with the mean length of newly hatched anchovy larvae found in other studies (García et al., 1981; Palomera et al., 2007; Sabatés et al., 2007). Larval growth up to yolk-sac resorption was approximated with the Farris (1960) and von Bertalanffy (1938) functions after Regner (1996). The growth of feeding larvae was approximated with a temperature-dependent linear function derived from Regner (1985). The threshold length distinguishing yolk-sac larvae from feeding larvae was set at $3.4 \mathrm{~mm}$ (Palomera et al., 1988). To ensure that the particle continued to grow at a minimum rate, a threshold temperature for the seawater was set to $13.6^{\circ} \mathrm{C}$ in the growth functions (King et al., 1978), and individuals were assumed to die below that temperature (see Mortality below). Growth, on the other hand, was assumed not to be limited (principally) by food, an assumption for which there is empirical and theoretical evidence (Jørgensen et al., 2014; Takahashi and Watanabe, 2005; Takasuka and Aoki, 2006).

Diel vertical migration (DVM): The biological processes affecting the vertical positions of eggs and larvae are recognized as critical components of realistic models of fish egg-larval dispersion (Brochier et al., 2008; Huret et al., 2010; Parada et al., 2008; 2003). Linked to larval growth, the DVM sub- 
model (Ospina-Alvarez et al., 2012b) calculated changes in the vertical position of larvae over time. The larvae performed DVM from the surface to an increasing depth that depended on their size, from hatch until $14 \mathrm{~mm}$, with a maximum of $60 \mathrm{~m}$ depth.

Mortality: There is evidence that the development of anchovy eggs and larvae at temperatures at or below $13.6^{\circ} \mathrm{C}$ results in either death or severe growth retardation, this being linked to high mortality either directly (King et al., 1978) or indirectly through predation (Anderson, 1988). A recent study of anchovy egg development, conducted by Bernal et al. (2012) in the Gulf of Cádiz, found that temperatures below $14^{\circ} \mathrm{C}$ and above $26^{\circ} \mathrm{C}$ result in high egg mortality rates. Here, we only included a deterministic term for mortality, using $13.6^{\circ} \mathrm{C}$ as a threshold. Further sources of mortality were not included.

\subsection{Analysis of model results}

Three model outputs were used as dependent variables to analyze the emerging properties of the SEIBM: modeled connectivity, R14 and the orthodromic distance. We selected the orthodromic distance (i.e., the average of the shortest distances between the initial and final positions of the propagules on the surface of a sphere) as an indicator of the differences in horizontal transport between the experiments. The orthodromic distance (hereafter termed distance) indicates dispersion (Pineda et al., 2007). Distances were measured based on code developed in MATLAB v7.12 (MATLAB, 2011) and compared using a Mann-Whitney-Wilcoxon test (MWW), unpaired and two-sided, based on code developed in R ( R Development Core Team, 2013). The effects of different variables on these three model outputs were analyzed using either Generalized Linear Models (GLMs) or GAMs, as explained below. In all cases, a model selection 
procedure based on the $\mathrm{F}$-test was used to retain only significant variables in the final model.

The modeled connectivity (number of R14 arrivals at each pre-defined nursery) is a count, bounded below at zero; a GLM with a Poisson error structure was fitted here. The first GLM included the year, month, day, zone and sea floor depth (at the release time) and their primary interactions as independent factors. In the final model, we kept the factors and primary interactions with the highest percentage of deviance. Because the R14 is in a success/failure format, a logit link, binomial error distribution was used in the GLM. The initial independent factors were as follows: year, month, day, zone, sea floor depth, seawater salinity and temperature (at the initial position) and all their primary interactions. For the distance travelled by each particle, a quasi-Poisson error structure with a log-link was used, as only positive values rounded to $\mathrm{km}$ were used in the analysis. We used the same procedure in the GLM for the R14 to select the independent factors in the first and final models. Each analysis above was performed using a multifactor analysis of variance in the GLM module of R (R Development Core Team, 2013).

Additionally, the effects of spawners' locations as a bidimensional spline (i.e., longitude and latitude) on the R14 were examined by GAMs with a binomial distribution and a natural cubic spline smoother (see Hastie and Tibshirani, 1990 for a detailed discussion). Model selection was performed only in relation to the degrees of freedom allowed to the spline, based on General Cross Validation (Wood, 2006). The final selected model was used to predict the influence of spawners' locations in R14 in the whole grid for the period 2003-2009. The predictions were returned on the scale of the response with approximate standard errors. Finally, the predicted influence of spawners' 
locations in R14 at each prediction grid cell was displayed as image plots using a spectral color gradient.

The connectivity matrices between the spawning areas and the nursery areas were also calculated for each spawning date based on the outputs of the SEIBM. Connectivity matrices describe the exchange rate between distant areas as the percentage of particles released from one spawning area (i.e., release zones) that recruit to other areas (i.e., nurseries) at the end of the transport simulation. Yearly mean connectivity matrices were calculated from the four matrices obtained for the same year for the years 2003-2009. Finally, an inter-annual mean connectivity matrix was calculated from the seven matrices obtained for each year. Following Watson et al. (2010), potential connectivity was defined as the probability of larval transport from the spawning to a nursery area (quantified from Lagrangian simulations for 10.000 particles, i.e. modeled connectivity), and the realized connectivity was the product of potential connectivity and larval production. The realized connectivity can be used to estimate larval recruitment patterns following Crooks and Sanjayan (2006). The potential connectivity per release zone was given by the sum along columns of the exchange rates of the connectivity matrix. The diagonal of a connectivity matrix gives the self-retention success (autochthonous R14). The cells outside of the diagonal represent the foreign success (alloch thonous R14). The information from the connectivity matrix was used to construct the directional linkages between release zones and larval recruitment zones, and the probability matrix defined the strength of connectivity.

The initial egg abundance estimates used to initialize the model and the SEIBM estimates of larvae that reach a nursery area, lagged one year, were compared with anchovy fishery data from the GoL (GFCM-SAC 2012) and a 
recruitment index specifically developed for the Catalan area. The observed recruitment index for the GoL (management FAO subarea GSA07) was based on the percentage of age- 0 anchovies derived from IFREMER surveys (GFCM-SAC 2012). For the Catalan area, we decided not to use the GSA06 recruitment estimates because they embrace a large area, which is actually disconnected from our model. Instead, we gathered monthly landings data from the Catalonian harbors from year 2002 to 2010 (Generalitat de Catalunya databases, available online http://www20.gencat.cat/portal/site/DAR/). As done in other works (Martín et al., 2008; 2011) we assumed that the fishery is driven by recruitment, as usually over $2 / 3$ of total biomass (and a larger proportion in numbers) is composed by age 0 and 1 (Scientific, Technical and Economic Committee for Fisheries (STECF), 2012) Further, on average, around 70\% of the landings are captured before august. Therefore, we built a recruitment proxy assuming that the landings between January and July of year $t$ (mostly ages 0 and 1 ) are representative of individuals produced in the year $\mathrm{t}-1$, as they cannot contain individuals older than 2 years or individuals produced the same year. In any case, this index was highly correlated to formal recruitment indices based on stock assessments for GSA06 ( $\mathrm{r}=0.75)$.

The goodness of SEIBM lagged one year (hereafter SEIBM-1) on the anchovy fishery indices was analyzed using linear regression, GAMs and Multivariate adaptive regression splines (MARS). MARS is a nonparametric extension of generalized linear models, automatically allowing for non-linearities and interactions between variables. The MARS models use a nonparametric modeling approach that does not require assumptions about the form of the relationship between the predictor and dependent variables (Friedman, 1991). Therefore, GAMs and MARS approach were used to avoid the assumptions of normality or linearity. Model predictor (i.e. 
SEIBM-1 late larval recruits) was tested for statistical significance ( $\bullet \bullet 0.05)$. In GAMs, the total deviance compares the fit of the saturated model to the null model, thus, expresses the total variability around a fitted line which can be decomposed to explained and unexplained (error) variability.

\section{Results}

\subsection{Evaluation of the effect of explanatory variables on model results.}

A significant effect of the independent factors on modeled connectivity was found ( $p$-value < 0.001). The initial conditions of the SEIBM (i.e., release year, release zone, sea-floor depth range and selected interactions of these factors) explained $83.34 \%$ of the modeled connectivity. The sea floor depth at spawning time (42.06\% of the variability) and the release year $(19.04 \%)$ had important effects on modeled connectivity, followed by the interaction of both factors. The release year factor showed the long-term effects of the Northern Current and mesoscale variability. We kept the release zone in all final models. However, this factor explained less than $2 \%$ of the variance of the model (Table 1). The factors and levels with the highest contributions to modeled connectivity were the years 2005 and 2006 and the sea floor depths ranges of $[0 \bullet 75]$ and $[>75 \bullet 100]$.

The effect of explanatory variables on the R14 was also significant (p-value < 0.001 , Table 1 ), although in this case only $15.78 \%$ of the deviance was explained by the initial conditions (i.e., release year, release month, release zone, sea-floor depth range and temperature). It is, however, important to note that no information from the hydrodynamics conditions was incorporated in the model, resulting in the low percentage of deviance explained. The release year (11.03\%) had the largest effect on R14, whereas the only other significant effect was minor (2.83\%) and attributed to the sea floor depth at spawning time (Table 1). The level factors with the highest 
contributions to the R14 were the years 2005 and 2006 and the sea floor depth ranges of $[0 \bullet 75]$ and $[>75 \bullet 100]$. Significant but low contributions to the total variance were made by the month of June, the GoL E release zone and the temperature ranges of $[20.3 \bullet 21.9]$ and $[>21.9 \bullet 25.3]$.

The distance travelled by the particles in the SEIBM was also significantly affected by the independent factors as assessed through a GLM ( $\mathrm{p}$-value < 0.001 ). This model explained approximately $25.98 \%$ of the variance and indicated that the release year $(15.19 \%)$ had an important effect on the dispersion of particles. The contributions of the other significant factors to the total variance were low (Table 1). Equally, the effects of the hydrodynamics were not embedded in this GLM. The distance travelled is only considered from the spawning point to the late larval recruitment point.

\subsection{Effects of the spatial variability of the spawning zones on late-larval recruitment}

The average (over the years) spatial distribution of eggs that yielded positive R14 is shown in Fig. 5a. The zones of influence of the Rhône plume, coastal lagoons of Languedoc-Roussillon and GoL W were zones with high predictions of R14 (Fig. 5b). The spawning zones with the highest number of eggs being recruited (Fig. 5a) overlap with zones of high predictions of R14 (Fig. 5b). However, this was not always the case (e.g., $43^{\circ} 30^{\prime} \mathrm{N} 3^{\circ} 50^{\prime} \mathrm{E}$ ). The area of influence of the coastal lagoons of Languedoc-Roussillon had the highest number of individuals reaching the nursery areas $\left(>2 \times 10^{10}\right.$ ind.). However, this area was not used by spawning adults during all years under analysis. The spawning in this area was extremely intense in 2006 and 2007 (Fig. 3). In contrast, the GoL W and Rhône plume areas have moderate but constant egg production through the years. 


\subsection{Connectivity}

On average, higher exchange rates were observed between neighboring populations in the north-south direction (Fig. 6). The area with the highest realized connectivity was GoL W (> 3.5 $10^{12}$ individuals on average), representing $46.8 \%$ of the potential connectivity averaged over the years.

GoL W had an autochthonous potential connectivity higher than that of GoL E (28.6\% vs. 9.7\%, Fig. 6). The potential connectivity between the GoL and other zones was $36.2 \%$. The Palamós and Barcelona areas were reached by an important number of larvae coming from the north $(34.2 \%$ of the total recruited late larvae). The Palamós area was the zone with the highest potential connectivity with the established spawning zones in the GoL (22.9\%), followed by Barcelona (11.3\%). Despite being low, the potential connectivity (2.0\%) between the GoL and the Ebro delta represents important realized connectivity (approximately $1.5 \times 10^{11}$ individuals). Particles from the Gulf of Lions (GoL W and GoL E) area never supplied the southern late larval recruitment in the GoV and only sporadically supplied the Balearic Islands (Fig. 6).

Inter-annual differences in potential and realized connectivity were also apparent (Fig. 7). The GoL W and Palamós zones have the highest values of standard deviation of the connectivity matrix. In GoL W, the high standard deviation was a direct consequence of the high egg production in 2007 and the strong retention of the particles due to oceanographic mesoscale characteristics in the GoL in 2003, 2004, and July of 2008 and 2009. In Palamós, an additive and complex situation between sea current velocities; mesoscale eddies; retention and denso-dependency played an important role in the high variability observed, especially in 2006 and 2007 (Fig. 8). High annual variations in connectivity were observed in the NW Mediterranean 
late larval recruitment coming from the GoL. In 2005, 2006 and 2008, exchanges occurred preferentially southwards (the highest southwards exchanges occurring in 2005). Northwards exchanges were observed primarily in 2009, indicating bidirectional exchanges between GoL W and GoL E. The highest self-retention rates and the highest exchange rates between neighboring areas occurred in 2003 and 2009 (Fig. 8).

The main direction of transport of eggs and larvae produced in the GoL is southward due to the general flow pattern of the Northern Current. Additionally, we detected northward potential connectivity between GoL W and GoL E (7.3\% of the total recruited late larvae in the 2003-2009 period, see Fig. 6). The pooled positions of $14 \mathrm{~mm}$ larvae from all experiments show that more than $65 \%$ of released particles do not reach the predefined nursery areas after approximately 30 drifting days, most of them ending up in oceanic waters (Fig. 9). A high number of the total recruited late larvae averaged over the years reached the western coast of the Gulf of Lions, near $42^{\circ} 25^{\prime} \mathrm{N}$ $3^{\circ} 15^{\prime} \mathrm{E}$. Outside of the Gulf of Lions, the Palamós and Barcelona areas recruited elevated numbers of larvae in proportion to the nursery areas in the south. This is due to the proximity of spawning areas in the experiment and hydrographic and topographic characteristics, as the Northern Current turns eastward, conditioning the $\mathrm{GoV}$ as a frontier for the dispersion of eggs spawned in the GoL. When the Balearic Current, reinforced by the Northern Current, flows from the south following the Balearic slope below $250 \mathrm{~m}$, it acts as a front (Fig. 1). In this case, the particles did not reach the proposed nursery area in the Balearic Islands. Consequently, a considerable proportion of the particles moving northeastward ended up north of the Balearic Islands, near 40ํ40'N 3ํㅡㅇ'E (Fig. 9). 
In order to compare the SEIBM-1 recruitment index to a proxy for the observed recruitment, the first fact to be accounted for is that, according to our model, over $60 \%$ of the late larval recruits generated in GSA07 end up in the GSA07. Therefore, it is anticipated that (in absence for data on other anchovy sources or differential site-specific mortality) any match between model late larval recruitment and observed recruitment will be better for GSA07 than for GSA06.

There was a strong relationship between SEIBM-1 recruitment index and the GSA07 recruitment index based on IFREMER acoustic surveys of individual classified as age 0 (Fig. 10). The adjusted R-squared for the linear regression model for GSA07 index was 0.71, and SEIBM-1 recruitment index as predictor is significant at the 0.001 level. In a GAM with a quasi-Poisson distribution and integrated smoothness estimation, the SEIBM-1 recruitment index explained $55.3 \%$ of the GSA07 index (intercept p-value $<0.001$, SEIBM-1 p-value $<0.005$ ). Also, SEIBM-1 recruitment index showed a strong relationship with GSA07 index based on a quasi-Poisson regression and a univariate MARS model. The GR-squared, an estimate of the predictive power of the MARS model, was 0.41 , the RSS was $7.9 \mathrm{E}+12$ and the MARS R-squared was 0.53 .

\section{Discussion}

This work is the first connectivity study for early stages of anchovy in the NW Mediterranean, and we focused primarily on the interactions between the distribution of spawners, hydrodynamic variability and egg and larval dispersal. In a previous SEIBM experiment, where we used as the release positions at spawning the egg abundances recorded by surveys designed especially for that purpose, the six zones along the Gulf of Lions and Catalan sea (see Fig. 4 as geographic reference) exhibited a significant high effect on 
individual late larval recruitment success (approximately $73 \%$ of the explained variance, Ospina-Alvarez et al., 2013). In the present study, the use of two release zones is an appropriate approach, as the interest was in the inter-annual variation and macro-scale connectivity between the GoL and other areas along the Catalan Sea and Balearic Islands. Variation in the spawners' distribution was considered between years but not within years, and egg and larval mortality was taken into account only as temperaturedependent through development.

A key outcome of this work is that the realized larval connectivity in the NW Mediterranean is not uniform, with source and destination strengths varying among locations and years. Egg production, although spatially heterogeneous, had a significant but small effect on the spatial patterns of realized larval recruitment strength. However, we limited the source zones (i.e., release zones of particles) to the geographic range from the acoustic surveys in the GoL, in order to obtain inter-annual variation in the spatial coverage of the anchovy. When the spatial coverage is incremented, although at the cost of losing temporal resolution (Ospina-Alvarez et al., 2013), the effects of the release zones on the late larval recruitment were evidenced.

Our results indicated that the strong variability of modeled connectivity was due to differences among spawning years and the sea floor depth range at spawning time. The analysis performed to evaluate the effects of initial conditions on individual larval recruitment success underlined the importance of spawning year but minimized the effect of depth. The analysis performed on the distance travelled by the particles also confirmed that spawning year is the most important factor leading to the late larval recruitment and dispersion of the eggs and larvae of anchovy. The reason for such strong variability of late larval recruitment, transport and dispersion lies in the circulation of the 
NW Mediterranean (Fig. 1). Although spawners' locations were primarily concentrated in the area of influence of the Rhône plume throughout the time series, in 2006 and 2007 the locations had a focalized coastal distribution. This coastal pattern is reflected in the analyses where the seafloor depth at spawning time has a significant high effect on modeled connectivity. The modeled connectivity factor analysis performed with a GLM, which explores the initial conditions in a hydrodynamic context, shows that the high concentrations of spawners in the coastal lagoons of Languedoc-Roussillon in 2007 and 2008 were likely isolated events. Therefore, we should not overgeneralize the observed patterns.

The effects of sea floor depth on individual larval recruitment success and distance travelled for the particles were significant but small. This suggests that depth is not a factor conditioning the contributions of the spawning sites to larval recruitment and dispersion over the years. Our results agree with Daily Egg Production Method studies in which egg production in the 1990s (1992, 1993 and 1994) exhibited a more widespread distribution (García and Palomera, 1996), reaching greater depths, whereas in the 2000s (2007 and 2008) the eggs exhibited a more coastal pattern (Palomera et al., 2008). This could be related to the size of the stocks (Somarakis et al., 2004), which were clearly higher in the early 1990s than in the 2000s, when the egg patches were more concentrated and coastal (Palomera et al., 2008).

The distribution of spawners used in this work provides evidence for the hypothesis that European anchovy spawning in the NW Mediterranean is associated with zones of high production, such as the GoL, influenced by the plume of the Rhône River and strong episodic coastal winds. In this area, hydrographic processes that underlie enrichment phenomena are smaller in scale compared to other regions (e.g., Canary and Benguela Current 
systems), and this makes it difficult to find clear linkages between spawning and environment, in contrast with other regions in which such links have been clearly identified (Boyd et al., 1998; Parada et al., 2003; Rodríguez, 1990; Shelton, 1990; Twatwa et al., 2012). However, the temporal synchronicity of spawning, the physiological condition and age of the spawners and egg fertilization play important roles in dispersion despite not being completely understood (Pineda et al., 2007). In addition, Pethybridge et al. (2013), using a Dynamic Energy Budget (DEB) model, have found that instead of having a direct effect, similar to other environmental variables such as temperature, lower food regimes predominantly influence adult summer energy storage in anchovy prior to reproduction, thereby negatively affecting anchovy production. Moreover, the mesoscale oceanographic processes that control larval recruitment may have different roles depending on the area, season and scale, among other factors. For example, Catalan et al. (2013) found that the strong effect of hydrodynamics in the North Alboran Sea, SW Mediterranean, confines the recruitment zone to a very localized coastal band.

The observations in the GoL suggest that the spawning areas are not restricted by bathymetry (within a range) because if the areas with the highest productivity change over time, the spawners' locations also change. The field data show that not all of the zones predicted as having high potential success were occupied by anchovy spawners (Fig. 5). This is feasible in an area with a wide shelf such as the Gulf of Lions, where continental inputs and wind mixing processes can occur at different times and places (Millot, 1990). Although it is unlikely that we could forecast the coastal spawning areas with higher contributions to larval recruitment based on the effects of primary production, spawners' distribution and hydrodynamics (e.g. Ospina-Álvarez et al., 2013), these coastal areas could 
be identified through backwards prediction. On the other hand, the persistence of spawners and the high-predicted probability of larval selfrecruitment in the area of influence of the Rhône plume identify this area as an essential habitat for anchovy reproduction (Figs. 1, 6). Several studies have proven that the Rhône River outflow is related to a high density of anchovy eggs (García and Palomera, 1996; Palomera et al., 2007; Sabatés et al., 2007), but this is the first time that the area of influence of the Rhône plume has been identified as having a high probability of larval recruitment success. The influence of Rhône River suspended particles on surface water and sediment is observed west of the Rhône all over the Gulf area (Durrieu de Madron et al., 2000; Durrieu De Madron et al., 1990; Tesi et al., 2007). However, under windy and wavy conditions, the rapid mixing of the plume reduces the extent of the enhanced production zone (Naudin et al., 2001). Thus, biomass fluxes are more important in GoL W than in GoL E, especially in relation to wind forcing (Tusseau-Vuillemin et al., 1998). Our results do agree with a higher importance of GoL W, in agreement with the above reasoning and the observation that the Rhône River plume is mostly diverted towards the southwest (Naudin et al., 2001). The enhanced planktonic production in the western part of the Gulf of Lions can be linked with the discharges from small mountainous rivers. For example, the Têt River can play a significant role in the supply of sediment to continental shelves and can contribute significantly to the export of sediment from the continental margin (Bourrin et al., 2008). Additionally, recent studies in other areas confer upon mesoscale dynamics a prominent role in shaping the early survival of coastalbound pelagic fish: Vásquez et al. (2013) found that the extent of the jack mackerel larvae distribution in the southeastern Pacific Ocean is determined by a two-step process involving, first, the existence of coastal waters containing copepod species, and second, the offshore propagation of mesoscale eddies bringing nutrient-rich waters from the shelf to adjacent 
oceanic waters. For anchovy in the NW Mediterranean, the inter-annual variability in the retention of eggs and larvae in the GoL might be linked with mesoscale processes related to the formation of sub-meso and mesoscale eddies (Ospina-Alvarez et al., 2012b). These eddies are generated by the accumulation of potential energy in the southwestern GoL and related to extreme wind events (Garreau et al., 2011). The timing of a bloom caused by eddy re-stratification depends on the lateral density gradient, wintertime mixed layer depth, the decrease in surface cooling below a threshold value, and wind speed and direction (Mahadevan et al., 2012). The circulation in the GoL is strongly related to wind schemes, and these wind structures have a short duration (Petrenko et al., 2008), but it is sufficient to generate eddies causing a phytoplankton bloom. Moreover, Campbell et al. (2013) have recently demonstrated that the planktonic production enhancement in the western part of the Gulf of Lions in summer is related to a combination of an upwelling zone north of Cape Creus and the persistence of a long-lived anticyclonic eddy that enables higher nutrient availability along the Roussillon coast in late summer.

The realized laryal connectivity in the NW Mediterranean was not uniform. The spawning and (potential) nursery areas varied strongly among locations and years. The inter-annual variability in hydroclimatic factors (e.g., wind speed and river run-off) induces high inter-annual variability of hydrological structures (Birol et al., 2010; Demirov and Pinardi, 2002; Fusco et al., 2003; Masó and Duarte, 1989). The predominant direction of egg and larval movement is southwestward following the Northern Current system, but the intra- and inter-annual variations substantially modify the general expectations. We occasionally detected northward connectivity within the GoL. Individual locations, although highly spatially heterogeneous, were shown to have a moderate effect on the spatial patterns of realized 
destination. These results strongly suggest that ocean circulation has a dominant role in directing anchovy larval recruitment patterns. There is a significant amount of retention in the spawning areas, indicating considerable potential for local larval recruitment in populations. The retention of successful larvae all over the Gulf of Lions area was high (approx. 60\%), particularly in 2003 and 2009. This result is in accordance with previous studies where, under certain oceanographic conditions, a DVM scheme optimizes retention while minimizing export and concentrates larvae in areas of lower salinity (Nicolle et al., 2009; Ospina-Alvarez et al., 2012b). In fact, anchovy larvae developing near the mouth of large rivers tend to be associated with the presence of less saline and more nutrient-rich waters at the surface (Boyra et al., 2003; Coombs et al., 1997; Palomera, 1992; Palomera et al., 2007; Sabatés et al., 2001). Connectivity patterns indicated that larval exchanges occurred primarily between and within the two spawning areas (i.e., GoL W and GoL E). The Ebro delta represents the maximum dispersal distance for eggs spawned in the GoL. The anchovy larvae from the GoL never supplied the southern early larval recruitment in the GoV. Although anchovy larvae reached the Balearic Islands, this event was not common and took place under particular hydroclimatic conditions (e.g., strong Northern Current, July of 2005). Qiu et al. (2010), in a zooplankton transport model with a DVM scheme, found that particles can be trapped in the Balearic Current and then aggregated in the associated North Balearic Front. A considerable proportion of the particles moving northeast ended up north of the Balearic Islands. Bakun (1996) proposed the 'ocean triad' concept to describe the suitability of spawning habitat. Three processes make up suitable habitat: 1) nutrient enrichment, 2) the concentration of nutrients and larvae, and 3) the retention of larvae near suitable habitat. However, we argue that the triad concept has been developed for upwelling areas and that retention most likely requires broader 
interpretation when the general circulation allows larvae to return to the shelf. In any case, anchovy larvae that are entrained into the main circulation pattern of the Northern Current will be transported offshore and consequently lost from coastal nursery grounds. The latter scenario could promote oceanic retention and, under suitable conditions, could generate an oceanic nursery habitat for anchovy. Based on our results, we consider it to be of high interest to test, in this study area, the hypothesis proposed by Irigoien et al. (2007) of anchovy using off-shore waters for juvenile recruitment.

Even before the present study, it was evident that GoL W is a potential nursery area (Nicolle et al., 2009). Connectivity matrices suggest that, despite a high inter-annual variability, the average percentage of recruited larvae in this area is the highest of all defined nursery areas (approximately $45 \%$ of total recruited larvae). As was already suggested previously by Sabatés et al. (2001), our study demonstrates a high level of connectivity between the Gulf of Lions and the Catalan Sea. Ospina-Alvarez et al. (2012b) found in a SEIBM experiment that the eggs spawned in the Palamós and Barcelona areas in 2007 and 2008 had a low probability of reaching nursery areas, for which there is wide evidence (Palomera et al., 2007). However, in the present study, we found that the Palamós and Barcelona zones accounted for approximately $35 \%$ of the total recruited larvae spawned in the GoL, thus acting as clear sinks. On the other hand, the Ebro delta continental shelf accounted for approximately $2 \%$ of the total recruited larvae spawned in the GoL. The importance of the Ebro River for anchovy fisheries, on the other hand, was highlighted in a SEIBM study showing that eggs spawned in the Ebro delta area had a high probability of reaching other nursery areas or being retained (Ospina-Alvarez et al., 2012b). Those results coupled to the present work confirm the transport of fish larvae from the GoL to the Ebro 
delta, promoting a unidirectional genetic flow between the two sites. Our results support the view that the healthy population in the Ebro delta may partly benefit from the high potential of and realized connectivity with the Gulf of Lions. The GoL anchovy population is not closed in the sense explained by Cowen et al. (2000), but our results support the view that retention is high and the larval income rate from southern areas is low. Thus, management policies for anchovy in the GoL should provide strategies that enhance self-recruitment. However, in a transboundary context, we propose that management policies should consider the connectivity of larval recruitment areas depending on distant source populations. These essential habitats for small pelagic fish should be protected through the establishment of a web of Marine Protected Areas coordinated by French and Spanish fisheries agencies and controlled by strict suryeillance, as suggested previously (de Juan and Lleonart, 2010; de Juan et al., 2012).

The SEIBM results indicate that high egg production does not imply high larval recruitment success, in agreement with stock-recruitment theory (Payne et al., 2008). Although we did not take into account larval predation or starvation, the larvae not reaching nursery areas was approximately $65 \%$, primarily due to unfavorable transport to oceanic waters. However, the interannual differences in realized connectivity found in this study hold a reasonable covariation with fluctuations in landings of age- 0 anchovy. This suggests a strong link between capable larvae and recruitment and that ocean circulation might play a central role in directing overall recruitment patterns. Although SEIBMs including early life history dispersal and larval recruitment success have been published (DeAngelis and Mooij, 2005; Gallego et al., 2007; Werner et al., 2001), most of these studies were not developed within a stock assessment framework. Spatiotemporal management can be an effective tool to manage quotas, but it requires spatially explicit 
estimates of resource abundance. The management implications are highly relevant because SEIBMs could provide operational information for predicting recruitment one year in advance. The present SEIBM should be undoubtedly improved in order to better represent mortality processes and fitness. To this respect, adding the effect of habitat quality and condition (e.g. Ferron and Leggett, 1994; Jørgensen et al., 2014; Takasuka and Aoki, 2006) and a bioenergetics growth model (e.g. Pethybridge et al., 2013; Politikos et al., 2011) are feasible options given the available data. Such an improved version of the model presented here, based on a R14 recruitment index, could be used to predict abundance indices and propose adequate fishing effort far enough in advance. The anchovy population in the Northwestern Mediterranean is a shared stock between France and Spain. We claim that our model could contribute to improved management strategies, including recruitment predictions based on potential distribution areas.

\section{Conclusions}

The present work is one of the first modeling studies that considered the transport of fish larvae in the NW Mediterranean using real-time hydrodynamic forcing, spawning behaviour, addressing inter-annual variability and incorporating physiological and behavior rules (egg development and buoyancy, larval growth and DVM). The connectivity between the GoL and Catalan coast was identified as being primarily southward but occasionally a two-way phenomenon. GoL W was identified as an important nursery habitat, and we highlighted the characteristics of the Ebro delta continental shelf to most likely maintain a healthy genetic flow of anchovy in the NW Mediterranean. The spatiotemporal patterns of larval recruitment were evaluated, and the results showed reasonable covariation with observed recruitment indices. We contend that an index based on the projected number of late larvae recruited could be used to optimize current 
assessment methods. The improvement of the model by including habitat quality, induced behavior (e.g., foraging, predator avoidance, schooling, directional horizontal swimming in response to environmental cues), and emerging properties (i.e., condition, mortality) may improve our understanding of the effects of fishing on metapopulations and the sustainable management of ecosystems threatened by overexploitation and climate change.

\section{Acknowledgements}

This research was conducted within the European project SARDONE (FP644294) and it is a contribution to the EU 7th Framework project called "Perseus (Policy-oriented marine environmental research for the Southern European Seas)". A. Ospina-Alvarez benefited from a PhD grant of the JAE program (CSIC). We are grateful to P. Garreau for his support with MARS3D hydrodynamic model outputs, as well as to P. Verley for his assistance in ICHTHYOP code. Finally, the authors gratefully acknowledge the assistance of the captain, crew and scientific team of the RV L'Europe for their help during the cruises.

\section{References}

Anderson, J.T., 1988. A review of size dependent survival during pre-recruit stages of fishes in relation to recruitment. J. Northwest Atl. Fish. Sci. 8, 55-66.

André, G., Garreau, P., Garnier, V., Fraunie, P., 2005. Modelled variability of the sea surface circulation in the North-western Mediterranean Sea and in the Gulf of Lions. Ocean Dynam. 55, 294-308. doi:10.1007/s10236-005-0013-6

Arakawa, A., Lamb, V.R., 1977. Computational design of the basic dynamical processes of the UCLA general circulation model. General circulation models of the atmosphere, in: Chang, J. (Ed.), Methods in Computational Physics: Advances in Research and Applications. Academic Press, San Francisco, pp. 173165.

Arkema, K.K., Abramson, S.C., Dewsbury, B.M., 2012. Marine ecosystem-based management: from characterization to implementation. Front. Ecol. Environ. 4, 525-532. doi:10.1890/15409295(2006)4[525:MEMFCT]2.0.CO;2

Ayata, S.-D., Lazure, P., Thiébaut, É., 2010. How does the connectivity between populations mediate range limits of marine invertebrates? A case study of larval dispersal between the Bay of Biscay and the English Channel (North-East Atlantic). Prog. Oceanogr. 87, 18-36. doi:10.1016/j.pocean.2010.09.022

Bakun, A., 1996. Patterns in the ocean: Ocean processes and marine population dynamics. University of California Sea Grant, in cooperation with Centro de Investigaciones Biológicas de Noroeste, La Paz, Baja California Sur, Mexico, San Diego.

Barange, M., Coetzee, J., Takasuka, A., Hill, K., Gutierrez, M., Oozeki, Y., van der Lingen, C., Agostini, V., 
2009. Habitat expansion and contraction in anchovy and sardine populations. Prog. Oceanogr. 83, 251260. doi:10.1016/j.pocean.2009.07.027

Bartsch, J., Reid, D.G., Coombs, S.H., 2004. Simulation of mackerel (Scomber scombrus) recruitment with an individual-based model and comparison with field data. Fish. Oceanogr. 13, 380-391. doi:10.1111/j.13652419.2004.00306.x

Basterretxea, G., Jordi, A., Catalán, I.A., Sabatés, A., 2012. Model-based assessment of local-scale fish larval connectivity in a network of marine protected areas. Fish. Oceanogr. 21, 291-306. doi:10.1111/j.13652419.2012.00625.x

Bernal, M., Jiménez, M.P., Duarte, J., 2012. Anchovy egg development in the Gulf of Cádiz and its comparison with development rates in the Bay of Biscay. Fish. Res. 117-118, 112-120. doi:10.1016/j.fishres.2011.04.010

Bernal, M., Stratoudakis, Y., Wood, S.N., Ibaibarriaga, L., Uriarte, A., Valdes, L., Borchers, D., 2011. A revision of daily egg production estimation methods, with application to Atlanto-Iberian sardine. 1. Daily spawning synchronicity and estimates of egg mortality. ICES J. Mar. Sci. 68, 519-527. doi:10.1093/icesjms/fsr001

Bertalanffy, L.V., 1938. A quantitative theory of organic growth (Inquiries on growth laws. II). Human biology $10,182-213$.

Birol, F., Cancet, M., Estournel, C., 2010. Aspects of the seasonal variability of the Northern Current (NW Mediterranean Sea) observed by altimetry. J. Marine Syst. 81, 297-311. doi:10.1016/j.jmarsys.2010.01.005

Bombace, G., 2001. Influence of climatic changes on stocks, fish species and marine ecosystems in the Mediterranean Sea. Arch. Oceanogr. Limnol. 22, 67-72.

Bourrin, F., Friend, P.L., Amos, C.L., Manca, E., Ulses, C., Palanques, A., Durrieu De Madron, X., Thompson, C.E.L., 2008. Sediment dispersal from a typical Mediterranean flood: The Têt River, Gulf of Lions. Cont. Shelf Res. 28, 1895-1910. doi:10.1016/j.csr.2008.06.005

Boyd, A.J., Shannon, L.J., Schülein, F., Taunton-Clark, J., 1998. Food, transport and anchovy recruitment in the southern Benguela upwelling system of South Africa, in: Durand, M.-H., Cury, P., Mendelssonhn, R., Claude, R., Bakun, A., Pauly, D. (Eds.), Global Versus Local Changes in Upwelling Systems. Orstom, Paris, pp. 195-209.

Boyra, G., Rueda, L., Coombs, S.H., Sundby, S., Ådlandsvik, B., Santos, M., Uriarte, A., 2003. Modelling the vertical distribution of eggs of anchovy (Engraulis encrasicolus) and sardine (Sardina pilchardus). Fish. Oceanogr. 12, 381-395.

Brickman, D., Smith, P.C., 2002. Lagrangian stochastic modeling in coastal oceanography. J. Atmos. Ocean. Tech. 19, 83-99.

Brochier, T., Lett, C., Tam, J., Freón, P., Colas, F., Ayón, P., 2008. An individual-based model study of anchovy early life history in the northern Humboldt Current system. Prog. Oceanogr. 79, 313-325. doi:10.1016/j.pocean.2008.10.004

Campbell, R., Diaz, F., Hu, Z., Doglioli, A., Petrenko, A., Dekeyser, I., 2013. Nutrients and plankton spatial distributions induced by a coastal eddy in the Gulf of Lion. Insights from a numerical model. Prog. Oceanogr. 109, 47-69. doi:10.1016/j.pocean.2012.09.005

Catalán, I.A., Macías, D., Solé, J., Ospina-Alvarez, A., Ruíz, J., 2013. Stay off the motorway: resolving the prerecruitment life history dynamics of the European anchovy in the SW Mediterranean through a spatiallyexplicit individual-based model (SEIBM). Prog. Oceanogr. 111, 140-153. doi:10.1016/j.pocean.2013.02.001

Chassignet, E.P., Hurlburt, H.E., Smedstad, O.M., Halliwell, G.R., Wallcraft, A.J., Metzger, E.J., Blanton, B.O., Lozano, C., Rao, D.B., Hogan, P.J., Srinivasan, A., 2006. Generalized vertical coordinates for eddyresolving global and coastal ocean forecasts. Oceanography 19, 118-129. doi:10.5670/oceanog.2006.95

Coombs, S., Giovanardi, O., Conway, D., Manzueto, L., Halliday, N., Barret, C., 1997. The distribution of eggs and larvae of anchovy (Engraulis encrasicolus) in relation to hydrography and food availability in the outflow of the River Po. Acta Adriat. 38, 33-47.

Cowen, R.K., Gawarkiewicz, G., Pineda, J., Thorrold, S.R., Werner, F.E., 2007. Population connectivity in marine systems: an overview. Oceanography 20, 14-21. doi:10.5670/oceanog.2007.26

Cowen, R.K., Lwiza, K.M.M., Sponaugle, S., Paris, C.B., Olson, D.B., 2000. Connectivity of marine populations: open or closed? Science 287, 857-859. doi:10.1126/science.287.5454.857

Crooks, K.R., Sanjayan, M., 2006. Connectivity Conservation. Cambridge University Press, Cambridge.

Cury, P.M., Bakun, A., Crawford, R.J.M., Jarre, A., Quiñones, R.A., Shannon, L.J., Verheye, H., 2000. Small pelagics in upwelling systems: patterns of interaction and structural changes in "wasp-waist" ecosystems. ICES J. Mar. Sci. 57, 603-618. doi:10.1006/jmsc.2000.0712

de Juan, S., Lleonart, J., 2010. A conceptual framework for the protection of vulnerable habitats impacted by fishing activities in the Mediterranean high seas. Ocean Coast. Manage. 53, 717-723. doi:10.1016/j.ocecoaman.2010.10.005 
de Juan, S., Moranta, J., Hinz, H., Barberá, C., Ojeda-Martinez, C., Oro, D., Ordines, F., Ólafsson, E., Demestre, M., Massutí, E., 2012. A regional network of sustainable managed areas as the way forward for the implementation of an Ecosystem-Based Fisheries Management in the Mediterranean. Ocean Coast. Manage. 65, 51-58. doi:10.1016/j.ocecoaman.2012.04.024

DeAngelis, D.L., Mooij, W.M., 2005. Individual-based modeling of ecological and evolutionary processes. Annu. Rev. Ecol. Evol. S. 36, 147-168.

Demirov, E., Pinardi, N., 2002. Simulation of the Mediterranean Sea circulation from 1979 to 1993: Part I. The interannual variability. J. Marine Syst. 33-34, 23-50. doi:10.1016/S0924-7963(02)00051-9

Doray, M., Massé, J., Petitgas, P., 2010. Pelagic fish stock assessment by acoustic methods at Ifremer. IFREMER R.INT. DOP/DCN/EMH 10-02, Nantes.

Dunne, J., Williams, R., Martinez, N., 2004. Network structure and robustness of marine food webs. Mar. Ecol.Prog. Ser. 273, 291-302. doi:10.3354/meps273291

Durrieu de Madron, X., Abassi, A., Heussner, S., Monaco, A., Aloisi, J.C., Radakovitch, O., Giresse, P., Buscail, R., Kerherve, P., 2000. Particulate matter and organic carbon budgets for the Gulf of Lions (NW Mediterranean). Oceanol. Acta 23, 717-730. doi:10.1016/S0399-1784(00)00119-5

Durrieu De Madron, X., Nyffeler, F., Godet, C.H., 1990. Hydrographic structure and nepheloid spatial distribution in the Gulf of Lions continental margin. Cont. Shelf Res. 10, 915-929. doi:10.1016/02784343(90)90067-V

FAO Fisheries Department, 2003. The ecosystem approach to fisheries. FAO Technical Guidelines for Responsible Fisheries No. 4, Suppl. 2. FAO, Rome.

Farris, D.A., 1960. The effect of three different types of growth curves on estimates of larval fish survival. ICES J. Mar. Sci. 25, 294-306. doi:10.1093/icesjms/25.3.294

Ferron, A., Leggett, W.C., 1994. An appraisal of condition measures for marine fish larvae. Adv. Mar. Biol. 30, 217-303.

Freón, P., Cury, P.M., Shannon, L.J., Roy, C., 2005. Sustainable exploitation of small pelagic fish stocks challenged by environmental and ecosystem changes: A review. Bull. Mar. Sci. 76, 385-462.

Friedman, J.H., 1991. Multivariate adaptive regression splines. The annals of statistics 19, 1-67.

Fusco, G., Manzella, G., Cruzado, A., Gacic, M., Gasparini, G., Kovacevic, V., Millot, C., Tziavos, C., Velasquez, Z., Walne, A., 2003. Variability of mesoscale features in the Mediterranean Sea from XBT data analysis. Ann. Geophys. 21, 21-32.

Gallego, A., North, E., Petitgas, P., 2007. Introduction: status and future of modelling physical-biological interactions during the early life of fishes. Mar. Ecol.-Prog. Ser. 347, 121-126. doi:10.3354/meps06972

Garcia, S.M., Rosenberg, A.A., 2010. Food security and marine capture fisheries: characteristics, trends, drivers and future perspectives. Philos. Trans. R. Soc. Lond., B, Biol. Sci. 365, 2869-2880. doi:10.1126/science. 1173146

García, A., Crespo, J., Rey, J., 1981. A contribution to knowledge of the Southern part of Spain's Mediterranean coastal zone including a description of a beach seine fishery. Presented at the Symposium on Management of living resources in the Mediterranean coastal area, Sep. 1980, Palma de Mallorca (Spain). Stud. Rev. Gen. Fish. Counc. Med. FAO No. 58, Rome.

García, A., Palomera, I., 1996. Anchovy early life history and its relation to its surrounding environment in the Western Mediterranean basin. Sci. Mar. 60, 155-166.

Garreau, P., Garnier, V., Schaeffer, A., 2011. Eddy resolving modelling of the Gulf of Lions and Catalan Sea. Ocean Dynam. 61, 991-1003. doi:10.1007/s10236-011-0399-2

Gaspar, P., Grégoris, Y., Lefevre, J.-M., 1990. A simple eddy kinetic energy model for simulations of the oceanic vertical mixing: tests at station Papa and long-term upper ocean study site. J. Geophys. Res. 95, 16179-16193. doi:10.1029/JC095iC09p16179

Grimm, V., Berger, U., DeAngelis, D.L., Polhill, J.G., Giske, J., Railsback, S.F., 2010. The ODD protocol: A review and first update. Ecol. Model. 221, 2760-2768. doi:10.1016/j.ecolmodel.2010.08.019

Grimm, V., Railsback, S.F., 2005. Individual-Based Modeling and ecology. Princeton University Press, New Jersey.

Hastie, T., Tibshirani, R.J., 1990. Generalized additive models. Chapman and Hall, London.

Hermann, A., Hinckley, S., Megrey, B.A., Napp, J.M., 2001. Applied and theoretical considerations for constructing spatially explicit individual-based models of marine larval fish that include multiple trophic levels. ICES J. Mar. Sci. 58, 1030-1041. doi:10.1006/jmsc.2001.1087

Hilborn, R., 2003. The state of the art in stock assessment: Where we are and where we are going. Sci. Mar. 67, 15-20. doi:10.3989/scimar.2003.67s115

Hinrichsen, H.-H., Dickey-Collas, M., Huret, M., Peck, M.A., Vikebø, F.B., 2011. Evaluating the suitability of coupled biophysical models for fishery management. ICES J. Mar. Sci. 68, 1478-1487. doi:10.1093/icesjms/fsr056

Huggett, J.A., Freón, P., Mullon, C., Penven, P., 2003. Modelling the transport success of anchovy Engraulis 
encrasicolus eggs and larvae in the southern Benguela: the effect of spatio-temporal spawning patterns. Mar. Ecol.-Prog. Ser. 250, 247-262. doi:10.3354/meps250247

Huret, M., Petitgas, P., Woillez, M., 2010. Dispersal kernels and their drivers captured with a hydrodynamic model and spatial indices: a case study on anchovy (Engraulis encrasicolus) early life stages in the Bay of Biscay. Prog. Oceanogr. 87, 6-17. doi:10.1016/j.pocean.2010.09.023

Irigoien, X., Fiksen, Ø., Cotano, U., Uriarte, A., Álvarez, P., Arrizabalaga, H., Boyra, G., Santos, M., Sagarminaga, Y., Otheguy, P., Etxebeste, E., Zarauz, L., Artetxe, I., Motos, L., 2007. Could Biscay Bay Anchovy recruit through a spatial loophole? Prog. Oceanogr. 74, 132-148. doi:10.1016/j.pocean.2007.04.011

Jørgensen, C., Opdal, A.F., Fiksen, Ø., 2014. Can behavioural ecology unite hypotheses for fish recruitment? ICES J. Mar. Sci. 71, 909-917. doi:10.1093/icesjms/fst083

Katara, I., Pierce, G.J., Illian, J., Scott, B.E., 2011. Environmental drivers of the anchovy/sardine complex in the Eastern Mediterranean. Hydrobiologia 670, 49-65. doi:10.1007/s10750-011-0693-5

Kendall, A., Ahlstrom, E.H., Moser, H.G., 1984. Early life history stages of fishes and their characters, in: Moser, H.G., Richards, W.J., Cohen, D.M., Fahay, M.P., Kendall, A., Richardson, S.L. (Eds.), Ontogeny and Systematics of Fishes: Based on an International Symposium Dedicated to the Memory of Elbert Halvor Ahlstrom. Amer. Soc. Ichthyol. Herpetol., Lawrence (USA), pp. 11-22.

King, D., Robertson, A., Shelton, P., 1978. Laboratory observations on the early development of the anchovy Engraulis capensis from the Cape Peninsula. Fish. Bull. S. Afr 10, 37-45.

Koutsikopoulos, C., Le Can, B., 1996. Physical processes and hydrological structures related to the Bay of Biscay anchovy. Sci. Mar. 60, 9-19.

Lazure, P., Dumas, F., 2008. An external-internal mode coupling for a 3D hydrodynamical model for applications at regional scale (MARS). Adv. Water Resour. 31, 233-250. doi:10.1016/j.advwatres.2007.06.010

Lejeusne, C., Chevaldonné, P., Pergent-Martini, C., Boudouresque, C.F., Pérez, T., 2010. Climate change effects on a miniature ocean: the highly diverse, highly impacted Mediterranean Sea. Trends Ecol. Evol. 25, 250-260. doi:10.1016/j.tree.2009.10.009

Lett, C., Verley, P., Mullon, C., Parada, C.E., Brochier, T., Penven, P., Blanke, B., 2008. A Lagrangian tool for modelling ichthyoplankton dynamics. Environ. Modell. Softw. 23, 1210-1214. doi:10.1016/j.envsoft.2008.02.005

Libralato, S., Christensen, V., Pauly, D., 2006. A method for identifying keystone species in food web models. Ecol. Model. 195, 153-171. doi:10.1016/j.ecolmodel.2005.11.029

Lomnicki, A., 1992. Population ecology from the individual perspective, in: DeAngelis, D., Gross, L.J. (Eds.), Individual-Based Models and Approaches in Ecology. Chapman and Hall, New York, pp. 3-17.

Mahadevan, A., D’Asaro, E., Lee, C., Perry, M.J., 2012. Eddy-driven stratification initiates North Atlantic spring phytoplankton blooms. Science 337, 54-58. doi:10.1126/science.1218740

Martín, P., Bahamon, N., Sabatés, A., Maynou, F., Sánchez, P., Demestre, M., 2008. European anchovy (Engraulis encrasicolus) landings and environmental conditions on the Catalan Coast (NW Mediterranean) during 2000-2005. Hydrobiologia 612, 185-199. doi:10.1007/s10750-008-9482-1

Martín, P., Sabatés, A., Lloret, J., Martin-Vide, J., 2011. Climate modulation of fish populations: the role of the Western Mediterranean Oscillation (WeMO) in sardine (Sardina pilchardus) and anchovy (Engraulis encrasicolus) production in the north-western Mediterranean. Clim Change 110, 925-939. doi:10.1007/s10584-011-0091-Z

Masó, M., Duarte, C.M., 1989. The spatial and temporal structure of hydrographic and phytoplankton biomass heterogeneity along the Catalan coast (NW Mediterranean). J. Mar. Res. 47, 813-827. doi: $10.1357 / 002224089785076145$

Massé, J., 1996. Acoustic observations in the Bay of Biscay: schooling, vertical distribution, species assemblages and behaviour. Sci. Mar. 60, 227-234.

MATLAB, 2011. V.7.12.0.635 (R2011a). The MathWorks Inc., Natick, Massachusetts.

Metaxas, A., Saunders, M., 2009. Quantifying the "Bio-" Components in Biophysical Models of Larval Transport in Marine Benthic Invertebrates: Advances and Pitfalls. Biol Bull 216, 257-272.

Millot, C., 1990. The Gulf of Lions' hydrodynamics. Cont. Shelf Res. 10, 885-894.

Mullon, C., Cury, P., Penven, P., 2002. Evolutionary individual-based model for the recruitment of anchovy (Engraulis capensis) in the southern Benguela. Can. J. Fish. Aquat. Sci. 59, 910-922. doi:10.1139/f02-064

Naudin, J.-J., Cauwet, G., Fajon, C., Oriol, L., Terzić, S., Devenon, J.-L., Broche, P., 2001. Effect of mixing on microbial communities in the Rhone River plume. J. Marine Syst. 28, 203-227. doi:10.1016/S09247963(01)00004-5

Needle, C.L., 2002. Recruitment models: diagnosis and prognosis. Rev. Fish Biol. Fish. 11, 95-111. doi:10.1023/A:1015208017674

Nicolle, A., Garreau, P., Liorzou, B., 2009. Modelling for anchovy recruitment studies in the Gulf of Lions 
(Western Mediterranean Sea). Ocean Dynam. 59, 953-968. doi:10.1007/s10236-009-0221-6

Olivar, M.P., Salat, J., Palomera, I., 2001. Comparative study of spatial distribution patterns of the early stages of anchovy and pilchard in the NW Mediterranean Sea. Mar. Ecol.-Prog. Ser. 217, 111-120. doi:10.3354/meps217111

Ospina-Alvarez, A., Bernal, M., Catalán, I.A., Roos, D., Bigot, J.-L., Palomera, I., 2013. Modeling fish egg production and spatial distribution from acoustic data: a step forward into the analysis of recruitment. PLoS ONE 8, e73687. doi:10.1371/journal.pone.0073687

Ospina-Alvarez, A., Palomera, I., Parada, C.E., 2012a. Changes in egg buoyancy during development and its effects on the vertical distribution of anchovy eggs. Fish. Res. 117, 86-95. doi:10.1016/j.fishres.2011.01.030

Ospina-Alvarez, A., Parada, C.E., Palomera, I., 2012b. Vertical migration effects on the dispersion and recruitment of European anchovy larvae: From spawning to nursery areas. Ecol. Model. 231, 65-79. doi:10.1016/j.ecolmodel.2012.02.001

Palomera, I., 1991. Vertical distribution of eggs and larvae of Engraulis encrasicolus in stratified waters of the western Mediterranean. Mar. Biol. 111, 37-44.

Palomera, I., 1992. Spawning of anchovy Engraulis encrasicolus in the Northwestern Mediterranean relative to hydrographic features in the region. Mar. Ecol.-Prog. Ser. 79, 215-223.

Palomera, I., Morales-Nin, B., Lleonart, J., 1988. Larval growth of anchovy, Engraulis encrasicolus, in the Western Mediterranean Sea. Mar. Biol. 99, 283-291.

Palomera, I., Olivar, M.P., Salat, J., Sabatés, A., Coll, M., García, A., Morales-Nin, B., 2007. Small pelagic fish in the NW Mediterranean sea: An ecological review. Prog. Oceanogr. 74, 377-396. doi:10.1016/j.pocean.2007.04.012

Palomera, I., Recasens, L., Libori, P., Alvarez-Calleja, I., Molí, B., Bahamon, N., 2008. Spawning stock biomass of the North Western Mediterranean anchovy in 2007. CGFM Tech. Doc. SCSA 2008 Anchovy GSA06 GSA07 DEPM. General Fisheries Commission for the Mediterranean (FAO), Izmir (Turkey).

Parada, C.E., 2003. Modeling the effects of environmental and ecological processes on the transport, mortality, growth and distribution of early stages of Cape Anchovy (Engraulis Encrasicolus) in the Benguela system. University of Cape Town, Cape Town.

Parada, C.E., Mullon, C., Roy, C., Freón, P., Hutchings, L., van der Lingen, C., 2008. Does vertical migratory behaviour retain fish larvae onshore in upwelling ecosystems? A modelling study of anchovy in the southern Benguela. African J. Mar. Sci. 30, 437-452. doi:10.2989/AJMS.2008.30.3.1.635

Parada, C.E., van der Lingen, C., Mullon, C., Penven, P., 2003. Modelling the effect of buoyancy on the transport of anchovy (Engraulis capensis) eggs from spawning to nursery grounds in the southern Benguela: an IBM approach. Fish. Oceanogr. 12, 170-184. doi:10.1046/j.1365-2419.2003.00235.x

Pauly, D., Christensen, V., 1995. Primary production required to sustain global fisheries. Nature 374, $255-257$. doi: $10.1038 / 374255 \mathrm{a} 0$

Pauly, D., Christensen, V., Guénette, S., Pitcher, T.J., 2002. Towards sustainability in world fisheries. Nature 418, 689-695. doi:10.1038/nature01017

Payne, M.R., Hatfield, E.M.C., Dickey-Collas, M., Falkenhaug, T., Gallego, A., Groger, J., Licandro, P., Llope, M., Munk, P., Rockmann, C., Schmidt, J.O., Nash, R.D.M., 2008. Recruitment in a changing environment: the 2000s North Sea herring recruitment failure. ICES J. Mar. Sci. 66, 272-277. doi:10.1093/icesjms/fsn211

Peck, M.A., Reglero, P., Takahashi, M., 2013. Life Cycle Ecophysiology of Small Pelagic Fish and Climatedriven Changes in Populations. Prog. Oceanogr. 116, 220-245. doi:10.1016/j.pocean.2013.05.012

Pethybridge, H., Roos, D., Loizeau, V., Pecquerie, L., Bacher, C., 2013. Responses of European anchovy vital rates and population growth to environmental fluctuations: An individual-based modeling approach. Ecol. Model. 250, 370-383. doi:10.1016/j.ecolmodel.2012.11.017

Petrenko, A., Dufau, C., Estournel, C., 2008. Barotropic eastward currents in the western Gulf of Lion, northwestern Mediterranean Sea, during stratified conditions. J. Marine Syst. 74, 406-428. doi:10.1016/j.jmarsys.2008.03.004

Pikitch, E., Boersma, P.D., Boyd, I.L., Conover, D.O., Cury, P.M., Essington, T., Heppell, S.S., Houde, E.D., Mangel, M., Pauly, D., Plagányi, É., Sainsbury, K., Steneck, R.S., 2012. Little fish, big impact: Managing a crucial link in ocean food webs, 1st ed. Lenfest Ocean Program, Wash. DC.

Pinardi, N., Allen, I., Demirov, E., De Mey, P., Korres, G., Lascaratos, A., Le Traon, P.Y., Maillard, C., Manzella, G., Tziavos, C., 2003. The Mediterranean ocean forecasting system: first phase of implementation (1998-2001). Ann. Geophys. 21, 3-20.

Pineda, J., Hare, J.A., Sponaugle, S., 2007. Larval transport and dispersal in the coastal ocean and consequences for population connectivity. Oceanography 20, 22-39. doi:10.5670/oceanog.2007.27

Politikos, D.V., Triantafyllou, G., Petihakis, G., Tsiaras, K., Somarakis, S., Ito, S.-I., Megrey, B.A., 2011. Application of a bioenergetics growth model for European anchovy (Engraulis encrasicolus) linked with a 
lower trophic level ecosystem model. Hydrobiologia 670, 141-163. doi:10.1007/s10750-011-0674-8

Qiu, Z., Doglioli, A., Hu, Z., Marsaleix, P., Carlotti, F., 2010. The influence of hydrodynamic processes on zooplankton transport and distributions in the North Western Mediterranean: estimates from a Lagrangian model. Ecol. Model. 221, 2816-2827. doi:10.1016/j.ecolmodel.2010.07.025

Quentin Grafton, R., Hilborn, R., Squires, D., Tait, M., Williams, M.J. (Eds.), 2010. Handbook of marine fisheries conservation and management. Oxford University Press, New York.

R Development Core Team, 2013. R: A Language and Environment for Statistical Computing. R Foundation for Statistical Computing, Vienna, Austria.

Regner, S., 1985. Ecology of planktonic stages of the anchovy, Engraulis encrasicolus (Linnaeus, 1758), in the central Adriatic. Acta Adriat. 26, 1-113.

Regner, S., 1996. Effects of environmental changes on early stages and reproduction of anchovy in the Adriatic Sea. Sci. Mar. 60, 167-177.

Reuter, H., Hölker, F., Middelhoff, U., Jopp, F., Eschenbach, C., Breckling, B., 2005. The concepts of emergent and collective properties in individual-based models-Summary and outlook of the Bornhöved case studies. Ecol. Model. 186, 489-501. doi:10.1016/j.ecolmodel.2005.02.014

Rodríguez, J.M., 1990. Contribución al conocimiento del ictioplancton del mar de Alborán. Bol. Inst. Espan. Oceanogr. 6, 1-20.

Sabatés, A., Salat, J., Olivar, M.P., 2001. Advection of continental water as an export mechanism for anchovy, Engraulis encrasicolus, larvae. Sci. Mar. 65, 77-87.

Sabatés, A., Salat, J., Palomera, I., Emelianov, M., Fernández de Puelles, M., Olivar, M.P., 2007. Advection of anchovy (Engraulis encrasicolus) larvae along the Catalan continental slope (NW Mediterranean). Fish. Oceanogr. 16, 130-141. doi:10.1111/j.1365-2419.2006.00416.x

Scientific, Technical and Economic Committee for Fisheries (STECF), 2012. Report for fisheries on assessment of Mediterranean sea stocks - part 1 (STECF 12-19). Publications Office of the European Union, Luxembourg. doi:10.2788/67440

Shelton, P., 1990. Ocean stability and anchovy spawning in the southern Benguela Current region. Fish. Bull. $88,3-338$.

Sibert, J., Hampton, J., Kleiber, P., Maunder, M., 2006. Biomass, size, and trophic status of top predators in the Pacific Ocean. Science 314, 1773-1776. doi:10.1126/science.1135347

Siegel, D.A., Mitarai, S., Costello, C.J., Gaines, S.D., Kendall, B.E., Warner, R.R., Winters, K.B., 2008. The stochastic nature of larval connectivity among nearshore marine populations. P. Natl. Acad. Sci. USA 105, 8974-8979. doi:10.1073/pnas.0802544105

Smagorinsky, J., 1963. General circulation experiments with the primitive equations. Mon. Weather Rev. 91, 99-164.

Smith, A.D.M., Brown, C.J., Bulman, C.M., Fulton, E.A., Johnson, P., Kaplan, I.C., Lozano-Montes, H., Mackinson, S., Marzloff, M., Shannon, L.J., Shin, Y.J., Tam, J., 2011. Impacts of fishing low-trophic level species on marine ecosystems. Science 333, 1147-1150. doi:10.1126/science.1209395

Somarakis, S., Nikolioudakis, N., 2010. What makes a late anchovy larva? The development of the caudal fin seen as a milestone in fish ontogeny. J. Plankton Res. 32, 317-326. doi:10.1093/plankt/fbp132

Somarakis, S., Palomera, I., García, A., Quintanilla, L., Koutsikopoulos, C., Uriarte, A., Motos, L., 2004. Daily egg production of anchovy in European waters. ICES J. Mar. Sci. 61, 944-958. doi:10.1016/j.icesjms.2004.07.018

Takahashi, M., Watanabe, Y., 2005. Effects of temperature and food availability on growth rate during late larval stage of Japanese anchovy (Engraulis japonicus) in the Kuroshio-Oyashio transition region. Fish. Oceanogr. 14, 223-235. doi:10.1111/j.1365-2419.2005.00334.x

Takasuka, A., Aoki, I., 2006. Environmental determinants of growth rates for larval Japanese anchovy Engraulis japonicus in different waters. Fish. Oceanogr. 15, 139-149. doi:10.1111/j.13652419.2005.00385.x

Tesi, T., Miserocchi, S., Goñi, M.A., Langone, L., 2007. Source, transport and fate of terrestrial organic carbon on the western Mediterranean Sea, Gulf of Lions, France. Mar. Chem. 105, 101-117. doi:10.1016/j.marchem.2007.01.005

Thorrold, S.R., Zacherl, D.C., Levin, L.A., 2007. Population connectivity and larval dispersal using geochemical signatures in calcified structures. Oceanography 20, 80-89. doi:10.5670/oceanog.2007.31

Treml, E.A., Roberts, J.J., Chao, Y., Halpin, P.N., Possingham, H.P., Riginos, C., 2012. Reproductive output and duration of the pelagic larval stage determine seascape-wide connectivity of marine populations. Integr. Comp. Biol. 52, 525-537.

Tusseau-Vuillemin, M.-H., Mortier, L., Herbaut, C., 1998. Modeling nitrate fluxes in an open coastal environment (Gulf of Lions): Transport versus biogeochemical processes. J. Geophys. Res.-Oceans 103, 7693-7708.

Twatwa, N., van der Lingen, C., Drapeau, L., Moloney, C., Field, J., 2012. Characterising and comparing the 
spawning habitats of anchovy Engraulis encrasicolus and sardine Sardinops sagax in the southern Benguela upwelling ecosystem. African J. Mar. Sci. 27, 487-499. doi:10.2989/18142320509504107

Vásquez, S., Correa-Ramírez, M., Parada, C.E., Sepúlveda, A., 2013. The influence of oceanographic processes on jack mackerel (Trachurus murphyi) larval distribution and population structure in the southeastern Pacific Ocean. ICES J. Mar. Sci. 70, 1097-1107. doi:10.1093/icesjms/fst065

Watson, J.R., Hays, C.G., Raimondi, P.T., Mitarai, S., Dong, C., McWilliams, J.C., Blanchette, C.A., Caselle, J.E., Siegel, D.A., 2011. Currents connecting communities: nearshore community similarity and ocean circulation. Ecology 92, 1193-1200. doi:10.1890/10-1436.1

Watson, J.R., Kendall, B.E., Siegel, D.A., Mitarai, S., 2012. Changing seascapes, stochastic connectivity, and marine metapopulation dynamics. Am Nat 180, 99-112. doi:10.1086/665992

Watson, J.R., Mitarai, S., Siegel, D.A., Caselle, J.E., Dong, C., McWilliams, J.C., 2010. Realized and potential larval connectivity in the Southern California Bight. Mar. Ecol.-Prog. Ser. 401, 31-48. doi:10.3354/meps08376

Werner, F.E., Cowen, R.K., Paris, C.B., 2007. Coupled biological and physical models: present capabilities and necessary developments for future studies of population connectivity. Oceanography 20,54-69. doi:10.5670/oceanog.2007.29

Werner, F.E., Quinlan, J.A., Lough, R.G., Lynch, D.R., 2001. Spatially-explicit individual based modeling of marine populations: a review of the advances in the 1990s. Sarsia 86, 411-421.

Wood, S.N., 2006. Generalized Additive Models: An Introduction with R (Chapman \& Hall/CRC Texts in Statistical Science), 1st ed. Chapman and Hall/CRC, London.

\section{List of figures}

Figure 1. Map of the study area in the Western Mediterranean Sea. The SEIBM domain (in the gray square).

Bathymetry is depicted in varying shades of blue. The areas corresponding to $<200,200-1000$ and $>1000$ $\mathrm{m}$ are shown in the map.

Figure 2. Conceptual diagram of the SEIBM. Input data, type of experiments, modeled variables and individualbased model for anchovy in NW Mediterranean coupled with a hydrodynamic model.

Figure 3. Output maps from Generalized Additive Models (GAMs) predicting the daily egg production from the PELMED and available fecundity data in the whole grid per year. The predictions were returned with approximate standard errors. The color-scales represent number of eggs per square $\mathrm{km}$.

Figure 4. Release (R) and nursery (N) zones in experiments: 1- GoL East (R, N), 2- GoL West (R, N), 3 Palamós (N), 4- Barcelona (N), 5- Ebro delta (N), 6- Gulf of Valencia (N) and 7- Balearic Islands (N). The color-scale represents the bathymetric contour in meters.

Figure 5. Spatial variability of spawning: a) SEIBM outputs of the inter-annual (2003-2009) mean density of eggs at spawning time including only eggs that recruited as late larvae and b) GAM predictions of R14 (deviance explained $6.8 \% ; \mathrm{p}<2 \times 10^{16}$ ). The color-scales represent number of eggs (a) and probability (b).

Figure 6. Connectivity matrix of mean recruited larvae. Potential connectivity, as the percentage of total recruited larvae coming from the same or another zone, is indicated in each cell. The color-scale represents the realized connectivity (mean recruited larvae $1 \times 10^{12}$ ).

Figure 7. Connectivity matrix of standard deviation of recruited larvae. The variability of the potential connectivity is indicated in each cell as the percentage of the variance of recruited larvae coming from the same or another zone. The color-scale represents the variability of realized connectivity (standard deviation of recruited larvae $1 \times 10^{12}$ ).

Figure 8. Matrix of annual potential connectivity in the Gulf of Lions and Balearic Sea. The annual realized connectivity $\left(1 \times 10^{12}\right)$ and the proportion of recruited larvae from the total eggs spawned, in parentheses, are indicated for each date (matrix). The color-scale represents the potential connectivity. 
Figure 9. Average number of recruited larvae in the NW Mediterranean from 2003 to 2009 in a SEIBM experiment releasing particles only from the Gulf of Lions. Density corresponds to larvae at $14 \mathrm{~mm}$ and not to a specific time from hatching. The recruitment zones are numbered, and 1 and 2 correspond also to spawning zones: 1- GoL East, 2- GoL West, 3- Palamós, 4- Barcelona, 5- Ebro delta, 6- Gulf of Valencia and 7 - Balearic Islands. The $250 \mathrm{~m}$ isobath is represented.

Figure 10. Time series of SEIBM index as percentage of late larval recruitment (year-1) and Catalonia and GSA07 indexes for anchovy in the NW Mediterranean. 


\section{List of tables}

Table 1. GLMs applied to the model output for the dependent variables "Modeled connectivity", "R14" and "Distance travelled". Analysis of deviance for GLM covariates and their interactions for the final model fitted. Abbreviations: df- degrees of freedom; Res. df- Residual degrees of freedom; Res. Dev- Residual deviance; $\%$ DE- Percentage of deviance explained. All $\chi 2$-statistics for the terms and their interactions were significant at $\mathrm{p}<0.01$. 


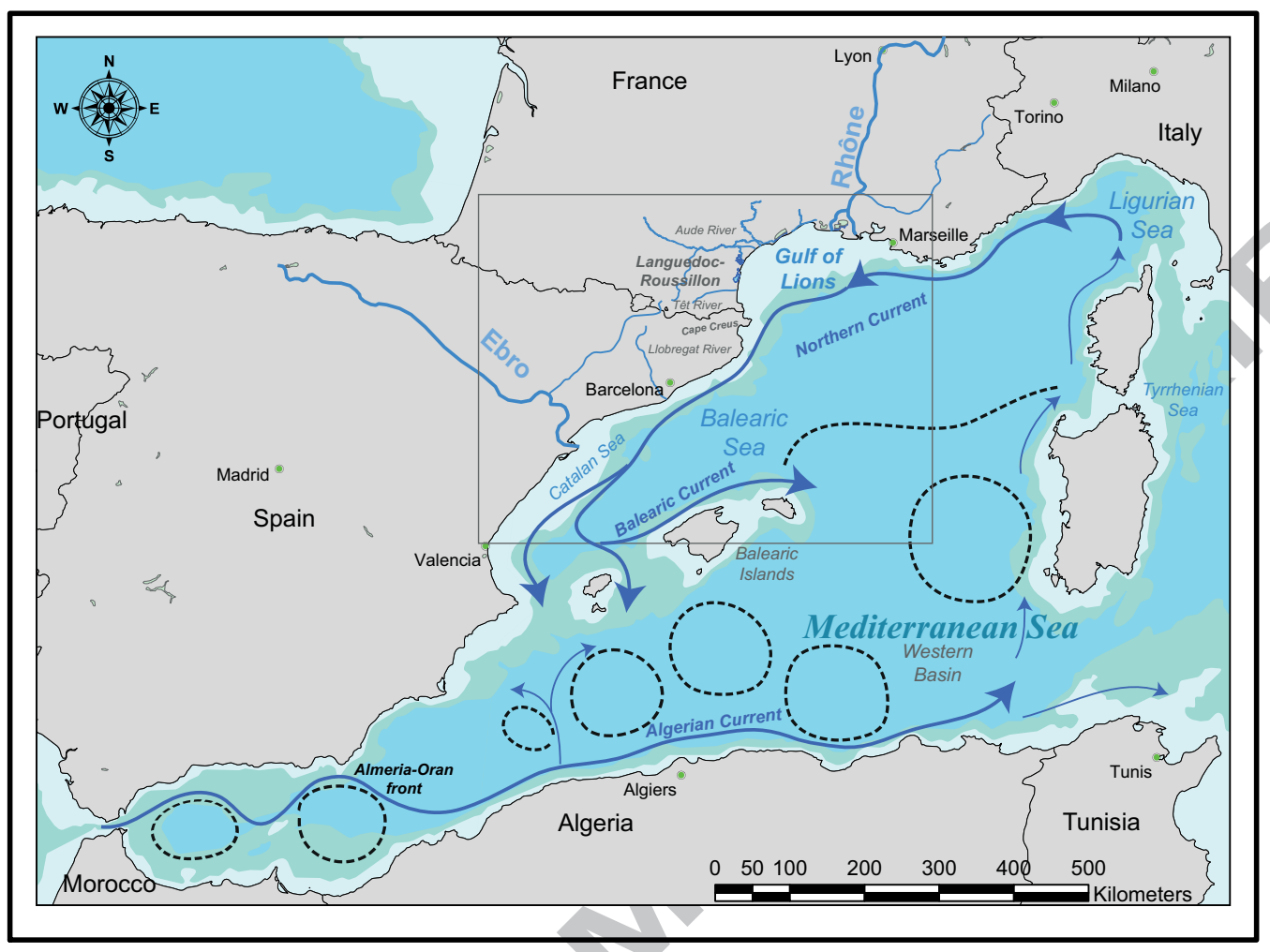




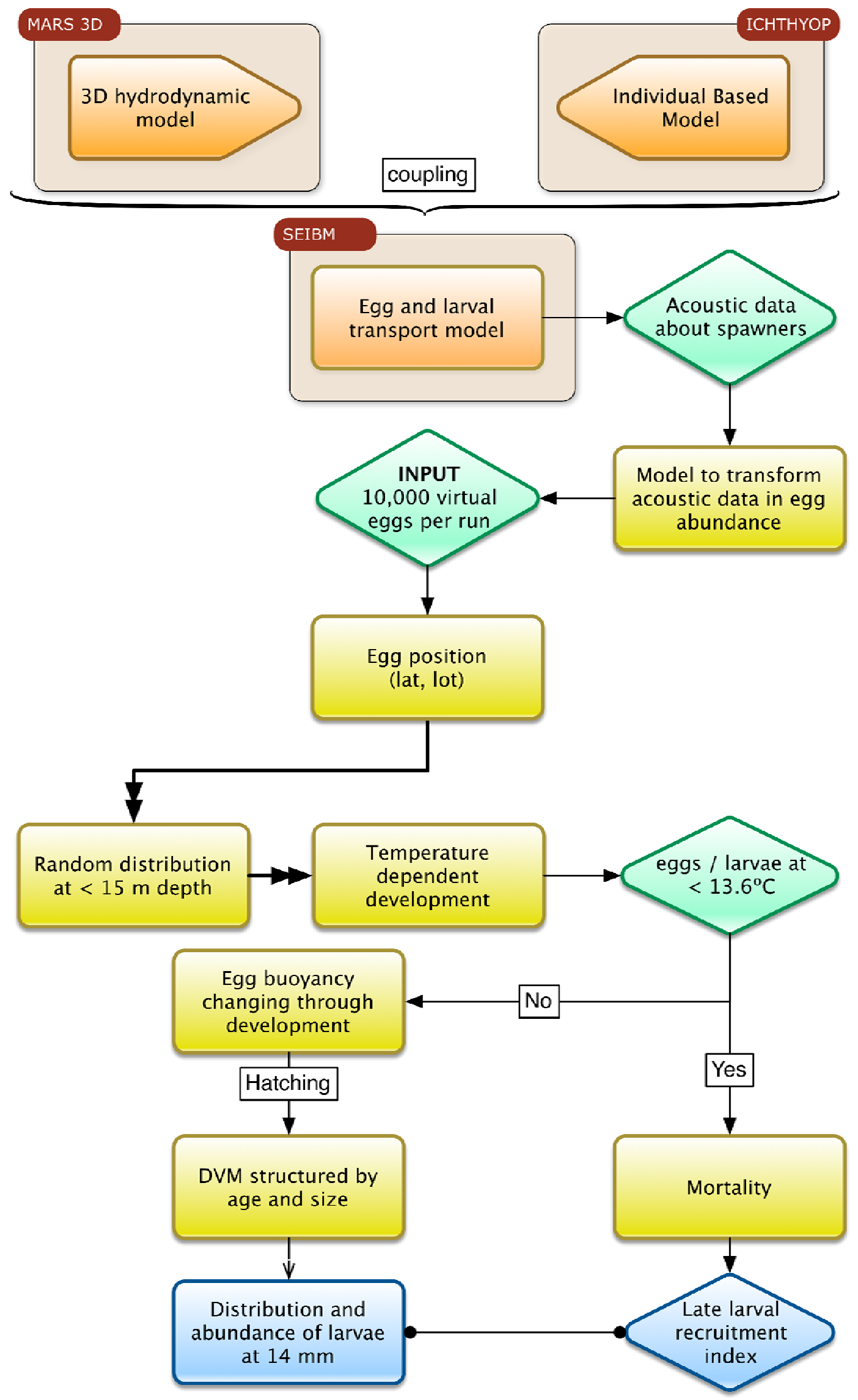



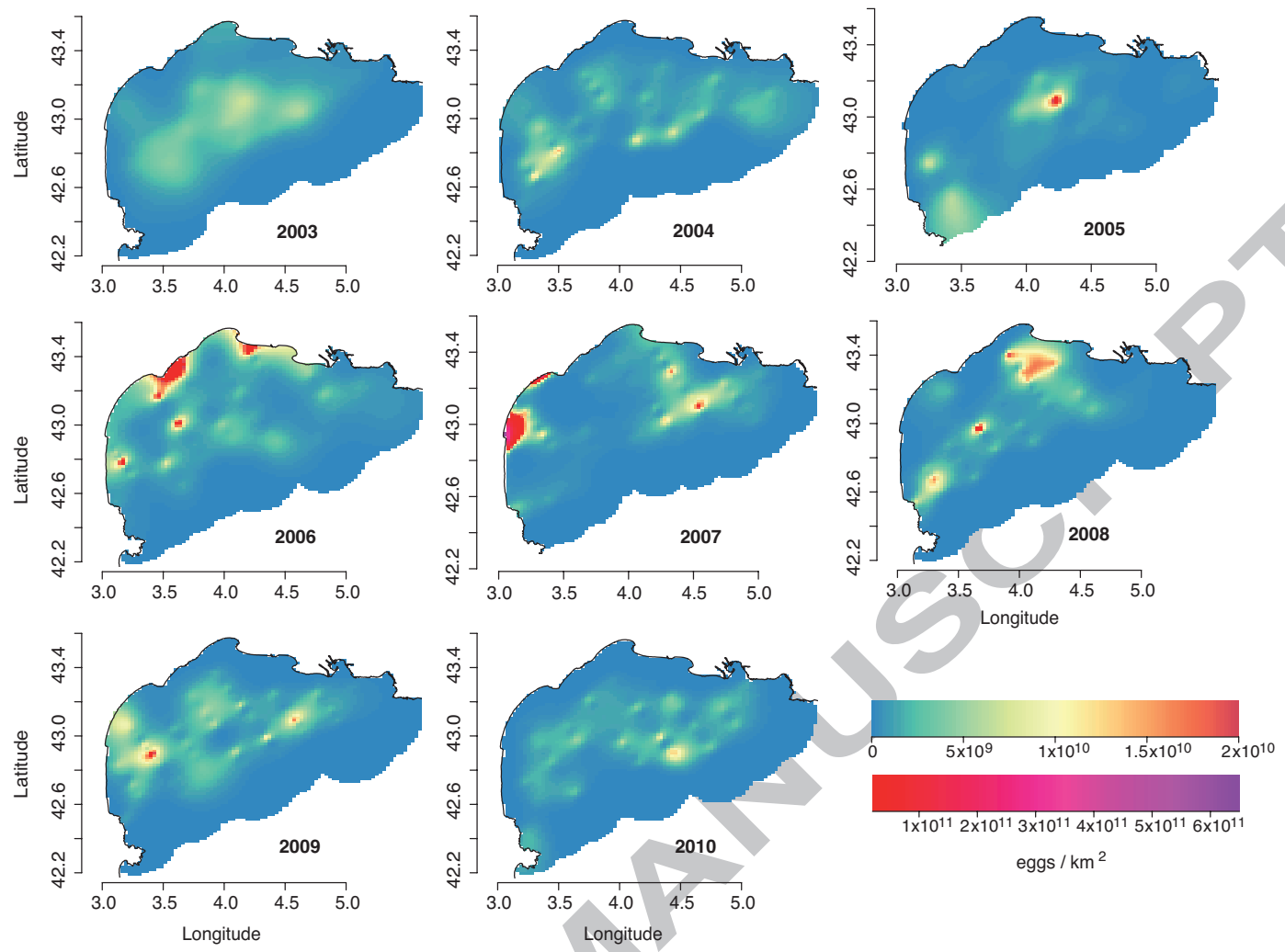


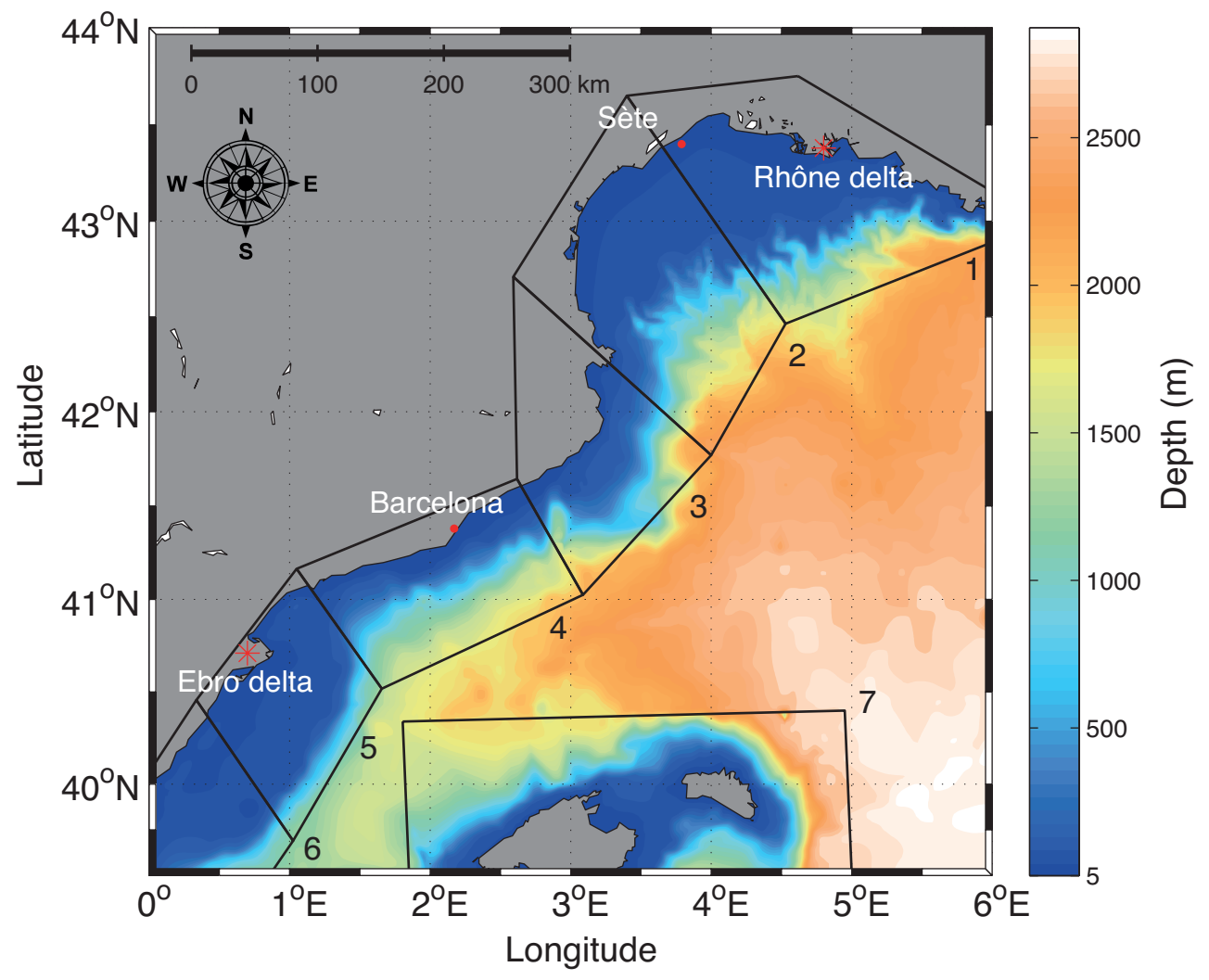


a)

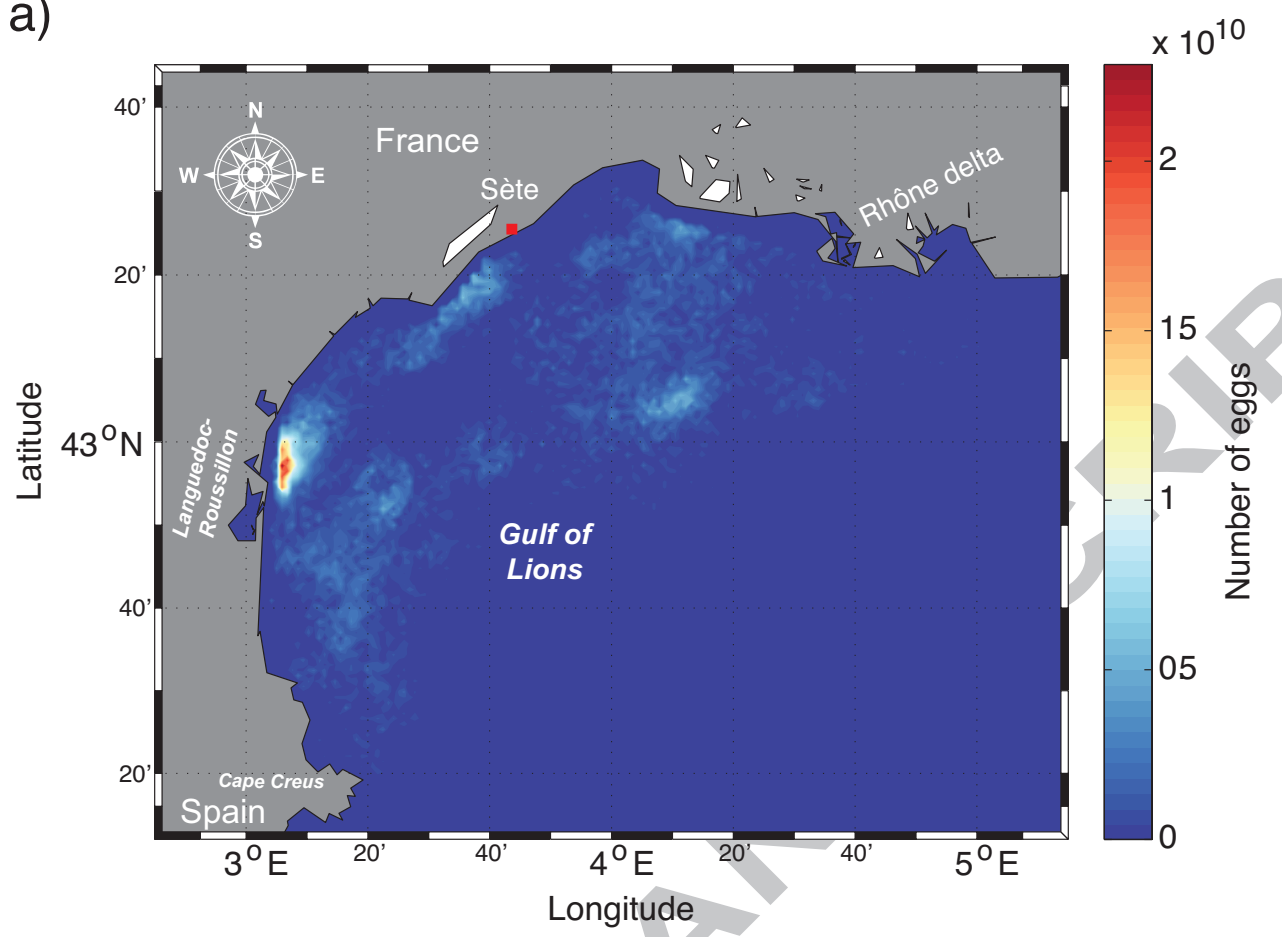

b)

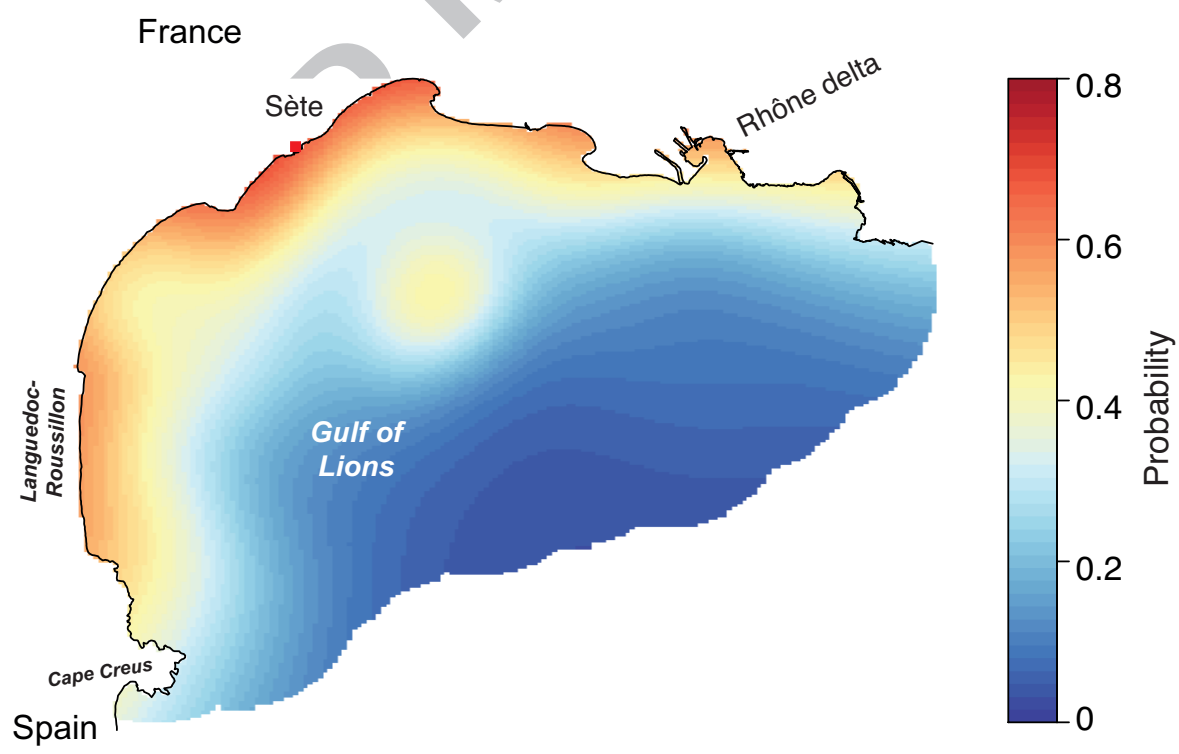




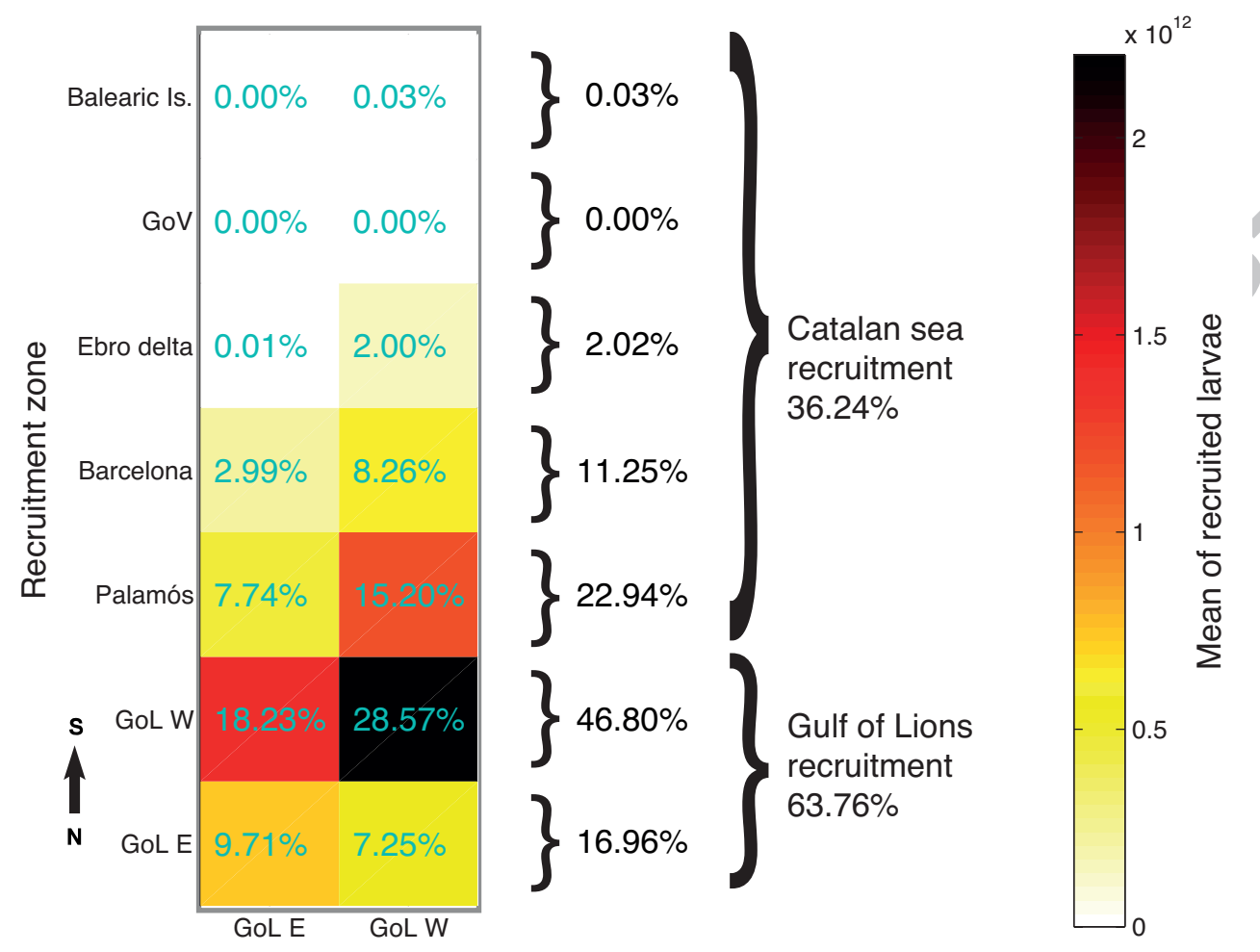

Spawning zone 


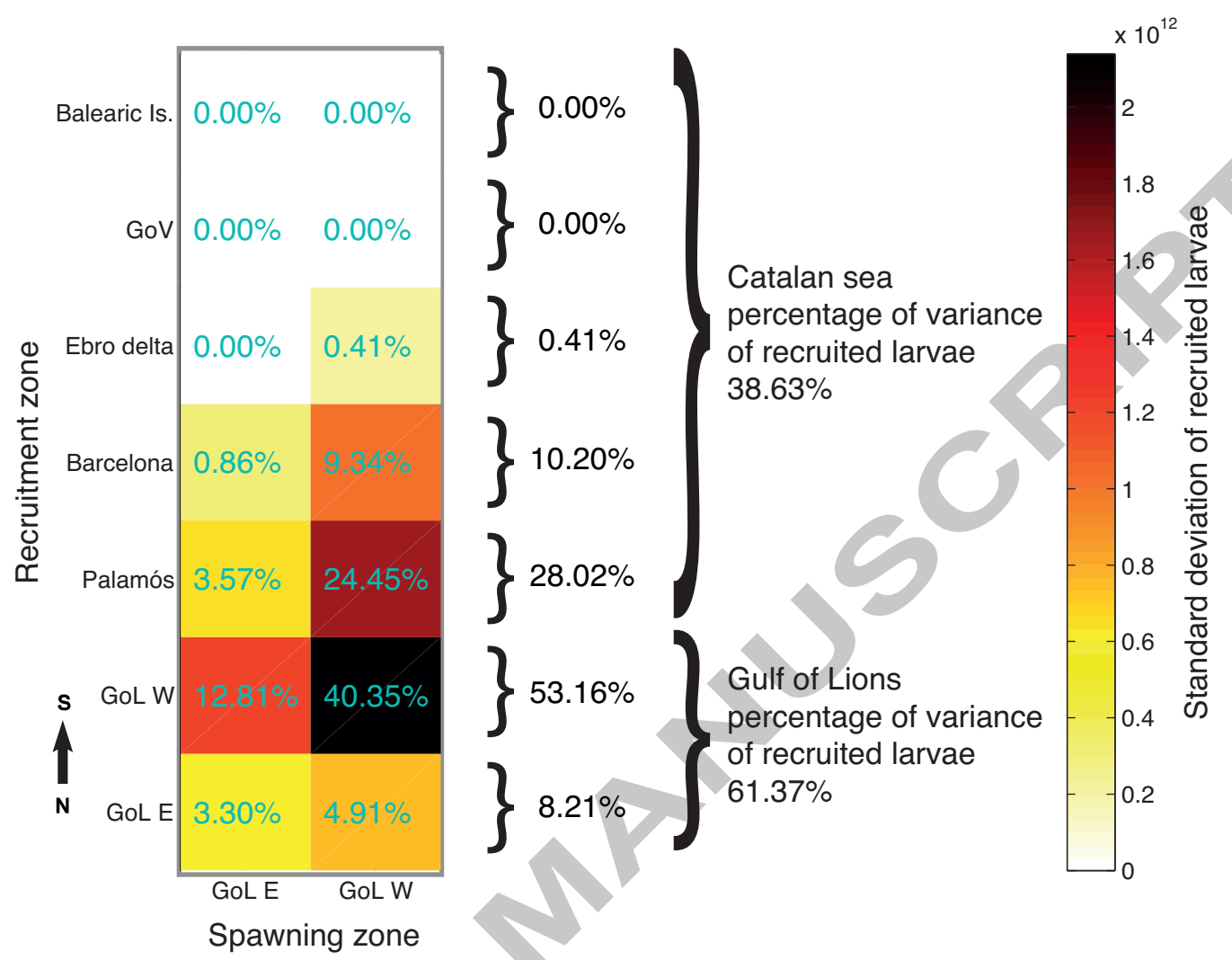




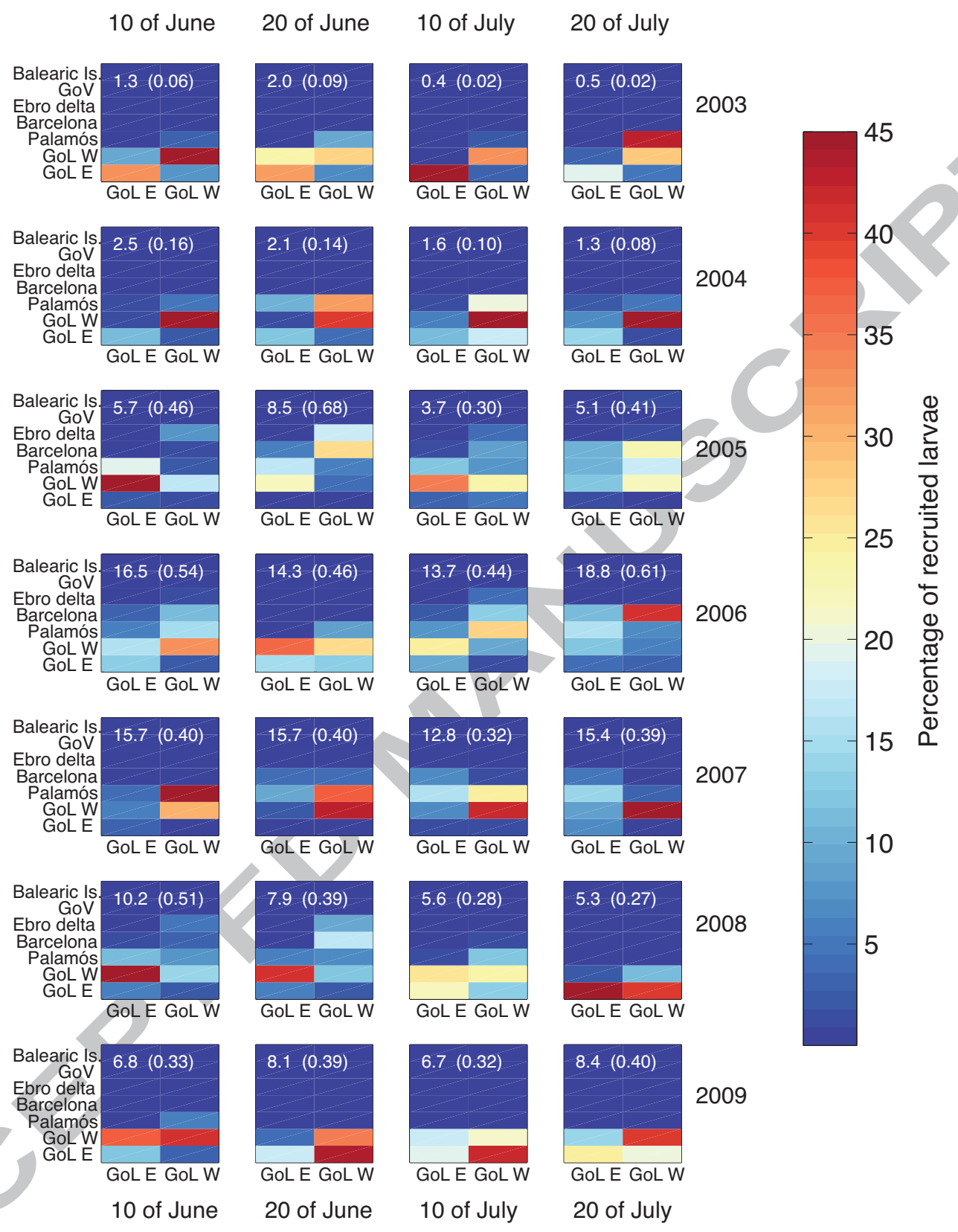




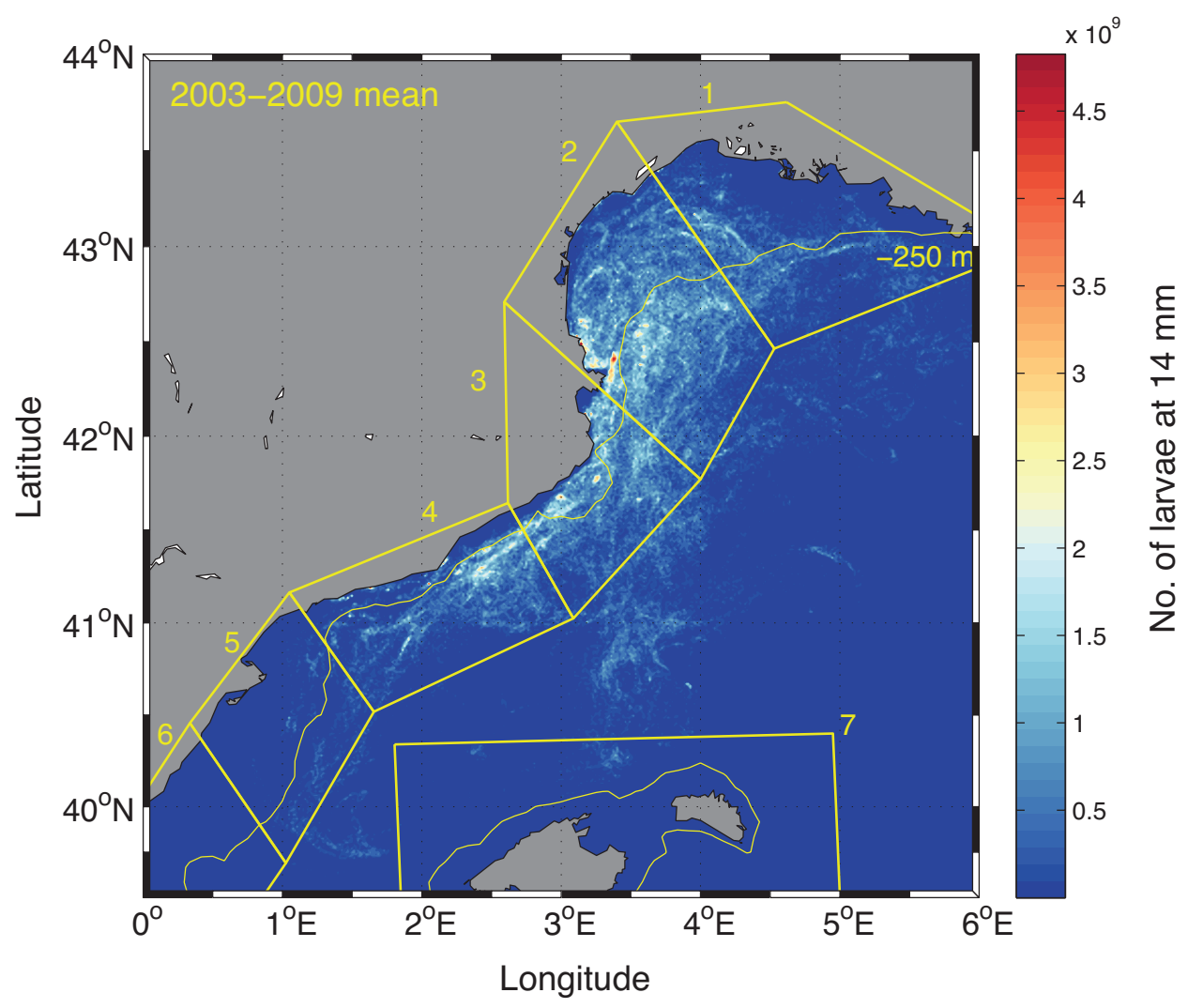




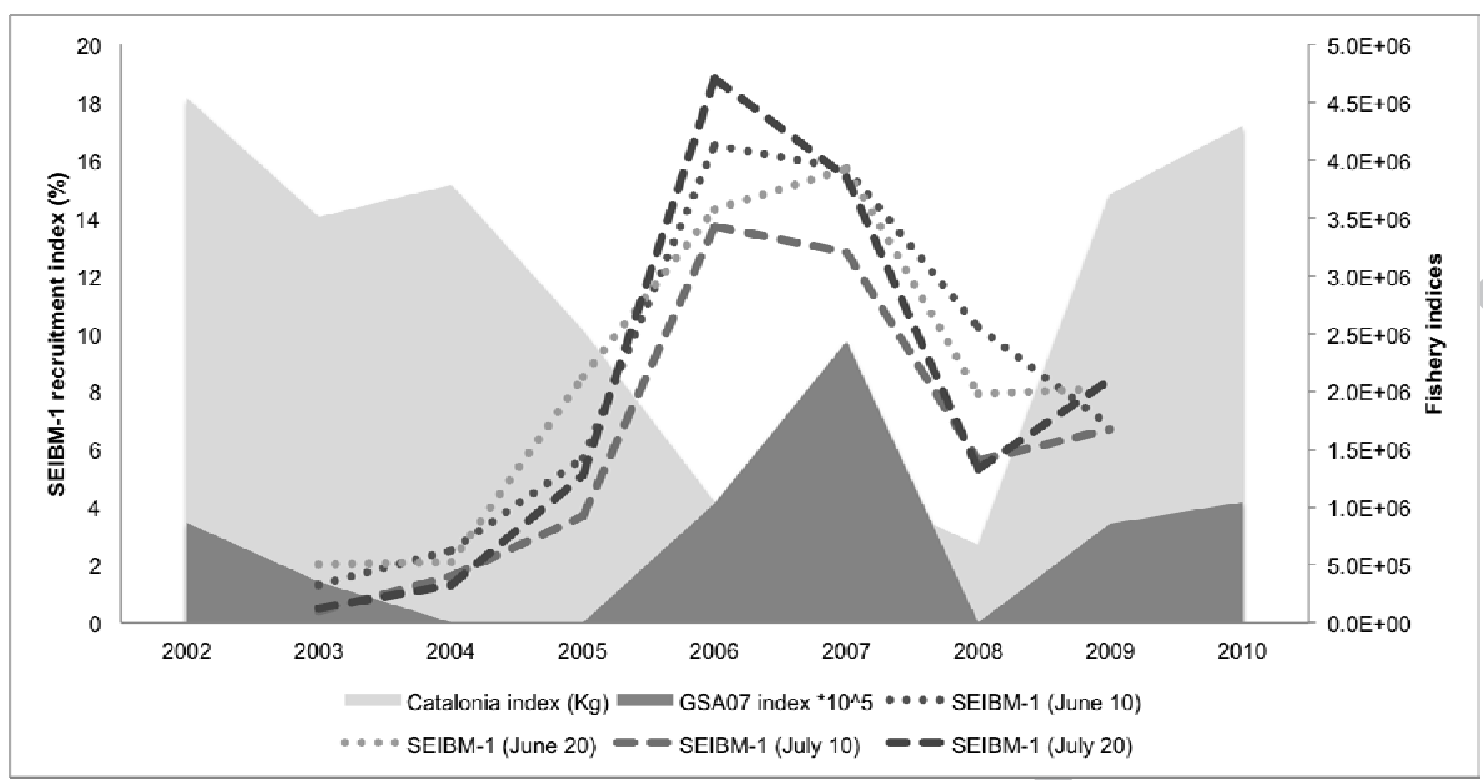




\begin{tabular}{|c|c|c|c|c|c|}
\hline Balanced GLI & Ddele & ectivity' & Family $=P$ & & \\
\hline terms & df & Deviance & Res. Df & Res. Dev & $\%$ DE \\
\hline NULL & & & 223 & 149422 & \\
\hline year & 6 & 28452 & 217 & 120970 & $19.04 \%$ \\
\hline relzone & 1 & 2726 & 216 & 118244 & $1.82 \%$ \\
\hline depth & 3 & 62846 & 213 & 55398 & $42.06 \%$ \\
\hline year:relzone & 6 & 5468 & 207 & 49930 & $3.66 \%$ \\
\hline year:depth & 18 & 24935 & 189 & 24995 & $16.69 \%$ \\
\hline relzone:depth & 3 & 1596 & 186 & 23399 & $1.07 \%$ \\
\hline & & & & TOTAL & $84.34 \%$ \\
\hline
\end{tabular}

Balanced GLM for R14

\begin{tabular}{ll|r|r|r|r}
\hline terms & df & Deviance & Res. Df & Res. Dev & $\%$ DE \\
\hline NULL & & & 279970 & 350840 & \\
\hline year & 6 & 38690 & 279964 & 312150 & $11.03 \%$ \\
month & 1 & 1208 & 279963 & 310942 & $0.34 \%$ \\
\hline relzone & 1 & 1088 & 279962 & 309854 & $0.31 \%$ \\
\hline depth & 3 & 9930 & 279959 & 299924 & $2.83 \%$ \\
\hline temperature & 4 & 4463 & 279955 & 295461 & $1.27 \%$ \\
\hline & & & & TOTAL & $15.78 \%$ \\
\hline
\end{tabular}

\begin{tabular}{|c|c|c|c|c|c|}
\hline \multicolumn{3}{|c|}{ Balanced GLM for 'Distance travelled' } & \multicolumn{3}{|c|}{ Family = quasipoisson (log) } \\
\hline terms & df & Deviance & Res. Df & Res. Dev & $\%$ DE \\
\hline NULL & & & 279970 & 22054952 & \\
\hline year & 6 & 3349632 & 279964 & 18705320 & $15.19 \%$ \\
\hline month & 1 & 336123 & 279963 & 18369197 & $1.52 \%$ \\
\hline relzone & 1 & 10338 & 279962 & 18358859 & $0.05 \%$ \\
\hline depth & 3 & 109987 & 279959 & 18248872 & $0.50 \%$ \\
\hline temperature & 4 & 628128 & 279955 & 17620744 & $2.85 \%$ \\
\hline year:relzone & 6 & 807440 & 279949 & 16813304 & $3.66 \%$ \\
\hline year:temp & 23 & 489099 & 279926 & 16324205 & $2.22 \%$ \\
\hline & & & & TOTAL & $25.98 \%$ \\
\hline
\end{tabular}

year: 2003, 2004, $20052006,2007,2008$ or 2009

month: June or July

release zone (relzone): 1- GoL East or 2- GoL West

sea floor (depth): [0 - 75], [> 75, 100], [> 100, 200], [> 200] meters

temperature: [13.4, 17.0], [17.0, 18.7], [18.7, 20.3], [20.3, 21.9], [21.9, 25.3] ${ }^{\circ} \mathrm{C}$ 